\title{
Endoplasmic Reticulum Stress Contributes to the Loss of Newborn Hippocampal Neurons after Traumatic Brain Injury
}

\author{
Kimberly N. Hood, Jing Zhao, John B. Redell, Michael J. Hylin, Brynn Harris, Alec Perez, Anthony N. Moore, \\ and Pramod K. Dash \\ Department of Neurobiology and Anatomy, the University of Texas McGovern Medical School, Houston, Texas 77225
}

Adult hippocampal neurogenesis has been shown to be required for certain types of cognitive function. For example, studies have shown that these neurons are critical for pattern separation, the ability to store similar experiences as distinct memories. Although traumatic brain injury (TBI) has been shown to cause the loss of newborn hippocampal neurons, the signaling pathway(s) that triggers their death is unknown. Endoplasmic reticulum (ER) stress activates the PERK-eIF2 $\alpha$ pathway that acts to restore ER function and improve cell survival. However, unresolved/intense ER stress activates C/EBP homologous protein (CHOP), leading to cell death. We show that TBI causes the death of hippocampal newborn neurons via CHOP. Using CHOP KO mice, we show that loss of CHOP markedly reduces newborn neuron loss after TBI. Injured CHOP mice performed significantly better in a context fear discrimination task compared with injured wild-type mice. In contrast, the PERK inhibitor GSK2606414 exacerbated doublecortin cell loss and worsened contextual discrimination. Administration of guanabenz (which reduces ER stress) to injured male rats reduced the loss of newborn neurons and improved one-trial contextual fear memory. Interestingly, we also found that the surviving newborn neurons in brain-injured animals had dendritic loss, which was not observed in injured CHOP KO mice or in animals treated with guanabenz. These results indicate that ER stress plays a key role in the death of newborn neurons after TBI. Further, these findings indicate that ER stress can alter dendritic arbors, suggesting a role for ER stress in neuroplasticity and dendritic pathologies.

Key words: context fear discrimination; dendritic shortening; loss of hippocampal newborn neurons; memory impairment; traumatic brain injury

\section{Significance Statement}

The hippocampus, a structure in the temporal lobe, is critical for learning and memory. The hippocampus is one of only two areas in which neurons are generated in the adult brain. These newborn neurons are required for certain types of memory, and are particularly vulnerable to traumatic brain injury (TBI). However, the mechanism(s) that causes the loss of these cells after TBI is poorly understood. We show that endoplasmic reticulum (ER) stress pathways are activated in newborn neurons after TBI, and that manipulation of the CHOP cascade improves newborn neuron survival and cognitive outcome. These results suggest that treatments that prevent/resolve ER stress may be beneficial in treating TBI-triggered memory dysfunction.

\section{Introduction}

Adult hippocampal neurogenesis has been shown to mediate certain types of cognitive function and affective behavior (Jessberger

Received June 23, 2017; revised Dec. 17, 2017; accepted Jan. 24, 2018.

Author contributions: P.K.D. designed research; K.N.H., J.Z., J.B.R., M.J.H., B.H., A.P., and A.N.M. performed research; K.N.H., J.Z., J.B.R., M.J.H., A.N.M., and P.K.D. analyzed data; J.Z., A.N.M., and P.K.D. wrote the paper.

This work was supported by NIH Grants NS090935, NS088298 and NS087149 to P.K.D, and by funds made available by the Gilson Longenbaugh Foundation and TIRR/Mission Connect. We thank Jacilyn MacGowan for maintaining the animal colonies and genotyping, and Dr. Mark Maynard for critical reading of the paper.

The authors declare no competing financial interests.

Correspondence should be addressed to Dr. Pramod K. Dash, Department of Neurobiology and Anatomy, The University of Texas Medical School, P.0. Box 20708, Houston, TX 77225. E-mail: p.dash@uth.tmc.edu. et al., 2009; Sahay et al., 2011; Opendak and Gould, 2015). Genetic lineage tracing experiments have shown that $\sim 30 \%$ of granule neurons in the rodent hippocampus are generated postnatally (Spalding et al., 2013). In humans, 0.004\% ( 700) new neurons are added to the hippocampus per day, which translates to a $1.75 \%$ turnover of cells each year (Spalding et al., 2013). Newborn neurons in the adult hippocampus are derived from a population of precursor cells located in the subgranular zone of the

M. J. Hylin's present address: Southern Illinois University, Department of Psychology, Life Science II 6502, Carbondale, IL 62901 .

DOI:10.1523/JNEUROSCI.1756-17.2018

Copyright $\odot 2018$ the authors $\quad 0270-6474 / 18 / 382372-13 \$ 15.00 / 0$ 
dentate gyrus. These newborn neurons express doublecortin, which has been used as a surrogate marker for monitoring adult neurogenesis. Over a period of $4-6$ weeks, these newly generated neurons integrate into the hippocampal circuit and begin to function as adult granule neurons (van Praag et al., 2002; Ambrogini et al., 2004). Computational and experimental studies have shown that new granule neurons are critical for pattern separation, the ability to distinguish and store similar experiences as distinct memories (Treves and Rolls, 1992; McClelland and Goddard, 1996). Consistent with this, ablation (via genetic knock-out or irradiation) of hippocampal neurogenesis in adult rodents impairs performance in the context fear discrimination task (Saxe et al., 2006). A failure to perform pattern separation may give rise to fear generalization as seen in people suffering from stress-related disorders (Kheirbek et al., 2012a).

Experimental studies have shown that doublecortin-positive newborn cells are highly vulnerable to traumatic brain injury (TBI; Gao et al., 2008; Gao and Chen, 2009; Sun et al., 2013; Gibb et al., 2015; Zhao et al., 2016). Fluoro-Jade staining of hippocampal sections from brain-injured animals indicated that newborn neurons die acutely after TBI and displayed fragmented nuclei, a feature of apoptosis (Gao et al., 2008). However, the signaling pathway(s) that triggers TBI-mediated apoptosis of newborn cells has not been identified. Unresolved or exaggerated endoplasmic reticular (ER) stress can trigger apoptotic cell death via activation of $\mathrm{C} / \mathrm{EBP}$ homologous protein (CHOP). To resolve ER stress, cells possess three sensors (referred to as ER stress sensors): inositol requiring enzyme 1 (IRE-1), activating transcription factor 6 (ATF6), and PKR-like ER kinase (PERK; Walter and Ron, 2011; Hotamisligil and Davis, 2016). In healthy cells, the chaperone protein Grp78 binds the ER membrane protein PERK and prevents its activation. As unfolded proteins accumulate in the ER in response to stress, Grp78 is dissociated from PERK, which then oligomerizes, leading to its activation. Active PERK phosphorylates eukaryotic initiation factor $2 \alpha$ (eIF2 $\alpha$ ), which inhibits general protein synthesis thereby allowing the cell time to resolve ER stress. However, translation of some mRNAs such as activating transcription factor 4 (ATF4) is not suppressed due to the presence of internal ribosome entry site on its mRNA. ATF4 protein increases expression of genes involved in protein folding and redox control (He et al., 2001; Wek and Cavener, 2007). If the ER stress is intense and cannot be resolved, ATF4 acts to increase the expression of CHOP, which initiates apoptotic cell death (Harding et al., 2000b).

In the present study, we used CHOP knock-out mice to examine the involvement of this protein in the TBI-triggered death of doublecortin-positive newborn cells in the hippocampus. Our findings indicate that loss of CHOP markedly reduces TBItriggered death of these cells and improves performance in a context discrimination task. We also demonstrate that pharmacological inhibition of PERK compromises the survival of these cells and dependent cognitive functions. Together, our results indicate that ER stress signaling pathways contribute to loss of newborn neurons following TBI.

\section{Materials and Methods}

Materials. One-hundred and five male C57BL/6 mice (25-30 g; 10-12 weeks of age) were purchased from ENVIGO Labs. Twenty-seven 10- to 12-week-old male CHOP homozygous-null mice (B6.129S-Ddit3 ${ }^{\mathrm{tm} 1 \text { Dron }} / \mathrm{J}$; RRID:IMSR_JAX:005530) were purchased from Jackson Laboratories. Fifty-three male Sprague Dawley rats (275-300 g; 10-12 weeks of age; RRID:RGD_5508397) were purchased from ENVIGO. Guanabenz was purchased from Tocris Bioscience), whereas GSK2606414 was pur- chased from Selleck Chemical. Antibodies against doublecortin (DCX; RRID:AB_2276960), phospho-eIF2 $\alpha$ (RRID:AB_390740), pan-eIF2 $\alpha$ (RRID:AB_2230924), phosphorylated PERK (RRID:AB_2095850), and cleaved caspase-3 (RRID:AB_2341188) were purchased from Cell Signaling Technology. Antibodies to NeuN (RRID:AB_2314891) and guinea pig anti-doublecortin (RRID:AB_1586992) were obtained from Millipore, whereas antibodies to CHOP (RRID:AB_2245733), Ki67 (RRID: AB_302459), and BrdU (RRID:AB_298940) were purchased from AbCam. 5-Bromo-2'-deoxyuridine (BrdU) was purchased from Sigma-Aldrich.

Genotyping. The CHOP knock-out mice (B6.129S(Cg)-Ddit3tm2.1Dron/J) used in the current study were originally generated by Dr. David Ron, NYU School of Medicine and were deposited for commercial use (Jackson Laboratories). The sequences of the $\mathrm{CHOP}$ genotyping primers are as follows: forward- 5' -ATGCCCTTACCTATCGTG-3', reverse 1- 5' -AAC GCCAGGGTTTTCCCAGTCA-3', reverse 2- 5'-GCAGGGTCAAGAG TAGTG-3'. Crude genomic DNA was isolated from mouse tissues using REDExtract-N-Amp Tissue PCR kit (Sigma-Aldrich) following the manufacturer's protocol. The isolated genomic DNA (1-2 $\mu \mathrm{l})$ was amplified in a $20 \mu \mathrm{l}$ reaction containing $1 \mu \mathrm{M}$ each primer using the following protocol: 1 cycle: $10 \mathrm{~min}, 95^{\circ} \mathrm{C} ; 35$ cycles: $30 \mathrm{~s}, 95^{\circ} \mathrm{C} / 1 \mathrm{~min}, 61^{\circ} \mathrm{C} / 1 \mathrm{~min}$, $72^{\circ} \mathrm{C}$; 1 cycle: $2 \mathrm{~min}, 72^{\circ} \mathrm{C}$. The amplified fragments (expected sizes: 320 bp for CHOP KO allele, 544 bp for WT allele) were separated on a $1.2 \%$ agarose gel in buffer containing $40 \mathrm{~mm}$ Tris-acetate and $1 \mathrm{~mm}$ EDTA, $\mathrm{pH}$ 8.3 , stained with ethidium bromide and photographed using the Syngene G:Box gel documentation system.

Production of cortical impact injury. Surgical procedures were approved by the Institutional Animal Care and Use Committee and were conducted in accordance with the recommendations provided in the Guide for the Care and Use of Laboratory Animals. Protocols were designed to minimize pain and discomfort during the injury procedure and recovery period. An electromagnet-driven controlled cortical impact (CCI) injury device was used to cause brain injury as previously described (Fischer et al., 2016; Osier and Dixon, 2016). Briefly, animals were anesthetized using $5 \%$ isoflurane with a $1: 1 \mathrm{O}_{2} / \mathrm{N}_{2} \mathrm{O}$ mixture, maintained under anesthesia using 2.5\% isoflurane with $1: 1 \mathrm{O}_{2} /$ air, mounted on a stereotaxic frame, and a midline incision was made. For mice, a 5 $\mathrm{mm}$ craniectomy was produced midway between the bregma and lambda with the medial edge of the craniectomy $0.5 \mathrm{~mm}$ lateral to the midline. Mice received a single impact ( $0.5 \mathrm{~mm}$ deformation) on the right parietal lobe with an impact velocity of $3 \mathrm{~m} / \mathrm{s}$ using a $3 \mathrm{~mm}$ impactor tip. For rats, the surgical procedures were identical except that the craniectomy was 7 $\mathrm{mm}$ in diameter, and the injury produced using a $5 \mathrm{~mm}$ tip traveling at 5 $\mathrm{m} / \mathrm{s}$ and a deformation of $2.5 \mathrm{~mm}$. Core body temperature was maintained at $37^{\circ} \mathrm{C}$ using a heating pad coupled with a rectal thermometer. Sham animals received all the surgical procedures except craniectomy and injury. After surgery, animals were given time to recuperate in a warming chamber before being returned to their home cages. Animals were weighed daily after the injury for the first $3 \mathrm{~d}$, then weekly thereafter.

Drug administration. A double-blinding procedure for coding study drugs was used to avoid potential bias. Drugs were prepared and coded to obscure their identity. The coded samples were given to a second experimenter who performed the injections. A third experimenter performed the cell counts or behavior. After the completion of the study, codes were broken for data analysis. GSK2606414 was dissolved in sterile saline containing 10\% DMSO and 8\% Captisol. Vehicle control animals received the same excipient mixture (10\% DMSO and 8\% Captisol). Injured (or sham-operated) mice were randomly assigned to receive either vehicle or $1.7 \mathrm{mg} / \mathrm{kg}$ GSK2606414 via intravenous injection initiated $30 \mathrm{~min}$ postinjury (or surgery). All animals received additional daily intraperitoneal injections for 2 more d. For biochemical evaluation of the effect of GSK2606414, mice were injected into the lateral ventricle $(-0.10 \mathrm{~mm}$ from bregma, $1.0 \mathrm{~mm}$ lateral to midline, $2.2 \mathrm{~mm}$ depth from the surface of the skull) with $10 \mu \mathrm{g}$ GSK2606414 (in $5 \mu \mathrm{l}$ ) or an equal amount of vehicle.

For experiments using guanabenz, rats were used as mice did not tolerate the drug. Guanabenz was dissolved in sterile saline to a concentration of $2.5 \mathrm{mg} / \mathrm{ml}$. Injured (or sham-operated) rats were randomly assigned to receive either vehicle or $5.0 \mathrm{mg} / \mathrm{kg}$ guanabenz via intraperi- 
toneal injection initiated 30 min postinjury. All animals received daily injections for a total of $3 \mathrm{~d}$.

Immunohistochemistry. Animals were killed by sodium pentobarbital overdose followed by exsanguination with saline and $4 \%$ paraformaldehyde. Brains were removed, postfixed in $4 \%$ paraformaldehyde overnight, and then cryoprotected in 30\% sucrose (in PBS). Forty-micron thick sections were prepared on a cryostat. For NeuN and doublecortin cell counts, selected sections ( $\sim-1.9 \mathrm{~mm}$ from bregma for mice; -3.3 $\mathrm{mm}$ from bregma for rats) were treated with $0.6 \% \mathrm{H}_{2} \mathrm{O}_{2}$, then permeabilized in PBS containing 0.25\% Triton X-100. After washing in PBS, sections were blocked in PBS containing 2\% BSA and 2.5\% normal goat serum for $2 \mathrm{~h}$, then incubated overnight in primary antibody $(0.5-1.0$ $\mu \mathrm{g} / \mathrm{ml}$ ) in blocking buffer. After extensive washing, sections were incubated in biotinylated secondary antibodies for $1 \mathrm{~h}$, washed, and then incubated in streptavidin-HRP for $45 \mathrm{~min}$. Immunoreactivity was visualized using diaminobenzidine. After color development, sections were mounted on gelatin-subbed slides, dehydrated using an alcohol series, clarified using xylene, and coverslipped with Permount (ThermoFisher).

For double-label immunohistochemistry, sections were permeabilized in PBS containing $0.25 \%$ Triton X-100, and blocked in PBS containing $2 \%$ BSA and $2.5 \%$ normal goat serum for $2 \mathrm{~h}$. Primary antibodies (in blocking buffer) were added and allowed to incubate overnight. After extensive washing, sections were incubated in species-specific secondary antibodies conjugated to AlexaFluors (Alexa-488 or Alexa-568) for $1 \mathrm{~h}$. After washing, sections were mounted and coverslipped with Fluoromount G (Southern Biotech).

$B r d U$ injection and detection. To label proliferating cells generated before injury, mice were injected with $50 \mathrm{mg} / \mathrm{kg} \mathrm{BrdU}$ (i.p.) for 3 weeks (3 injections/week). Five days after the last injection, mice were injured or sham operated. Three days after injury, mice were killed by sodium pentobarbital overdose followed by exsanguination with saline and $4 \%$ paraformaldehyde. Brains were removed, postfixed in $4 \%$ paraformaldehyde overnight, and then cryoprotected in $30 \%$ sucrose (in PBS). Freefloating slices ( $40 \mu \mathrm{m}$ thick) were prepared on a cryostat. Sections corresponding to $\sim-1.9 \mathrm{~mm}$ from bregma were selected, and then incubated in $2 \mathrm{~N} \mathrm{HCl}$ for $1 \mathrm{~h}$ followed by two washes ( $20 \mathrm{~min}$ each) of 0.1 M sodium borohydride. After extensive washing in PBS, immunohistochemistry for BrdU was performed as described above.

Cell and dendrite counting. Coded slides were counted by two independent observers who were blind to the treatment groups. Positive cells (doublecortin, BrdU, or Ki67) located in the granule layer of the dentate gyrus were counted and the lengths of the dentate gyrus measured. Doublecortin-positive dendrites that exited the granule cell layer and entered the molecular layer of the dentate gyrus were also counted. Immature neurons with dendrites reaching the molecular layer have been shown to be predominately postmitotic and are likely to be $>3 \mathrm{~d}$ old (Plümpe et al., 2006). The number of cells/mm was calculated from three sections (separated by $\sim 500 \mu \mathrm{m}$ ) for each animal.

NeuN-positive cells within the dentate gyrus subfield were counted using the optical dissector technique using Stereo Investigator (MicroBrightField Bioscience). The dentate gyrus was carefully outlined and subdivided using a $110 \times 100 \mu \mathrm{m}$ grid. The number of NeuN-labeled cells in $\sim 20$, computer-chosen areas within the dentate gyrus was scored for each section. The size of the counting frame, and the number of grid sections was determined based on preliminary cell counts. Cells in the outermost planes of focus $(5 \mu \mathrm{m})$ were omitted to avoid counting cell caps. The number of NeuN labeled cells $/ \mathrm{mm}^{3}$ for each section was obtained from the estimated cells divided by the contour volume. The number of cells $/ \mathrm{mm}^{3}$ for each animal was calculated as the average of the number of cells $/ \mathrm{mm}^{3}$ from each section examined.

Wes analysis. Protein concentrations were determined using a bicinchoninic acid protein assay (ThermoFisher Scientific Protein Biology). Equal amounts of protein for each sample were denatured in sample buffer (heated to $65^{\circ} \mathrm{C}$ ), and placed in the Wes Automated Western system (ProteinSimple), along with the primary and HRP-conjugated secondary antibodies. Sample separation, incubation, chemiluminescence, and quantification were performed automatically using preset parameters.
Assessment of cognitive function. Cognitive function was tested using tasks previously found to be dependent on adult hippocampal neurogenesis, namely the context discrimination and one-trial contextual fear tasks (Saxe et al., 2006; Kheirbek et al., 2012b). Mice were tested for their cognitive performance using the context discrimination task. Context discrimination was performed by pre-exposing animals for $10 \mathrm{~min}$ to two contexts. These contexts shared certain features (background noise, horizontal grid floor, animal handling to and from the room) but differed in others (cues, floor color, and scent). Animals were given two trials per day for $3 \mathrm{~d}$, one trial in each of the two chambers, as was done for the pre-exposure. One context was designated as the "shock" cage in which a $2 \mathrm{~s}, 1.0 \mathrm{~mA}$ shock was given at the end of the trial. No shock was administered in the "safe" cage. The cage chosen to be safe and the exposure order (e.g., safe then shock, or shock then safe) was randomized initially across animals, and the exposure order was maintained thereafter for each animal. The following day, discrimination between the two contexts was assessed by monitoring freezing behavior, at $2 \mathrm{~s}$ intervals in each of the two chambers. A reminder footshock was delivered in the shock cage and discrimination tested again $24 \mathrm{~h}$ later. The difference in freezing time in the shock versus safe cage was used as a measure of context fear discrimination. The consequence of guanabenz treatment in rats was assessed using a one-trial context-specific fear task. In this task, rats were placed in a training chamber for $2 \mathrm{~min}$, and then given a $2 \mathrm{~s}, 0.70 \mathrm{~mA}$ footshock. Thirty seconds after the shock, the rat was removed from the training chamber and returned to its home cage. Twenty-four hours later, memory was tested by placing the animal back into the training chamber and recording freezing behavior, in $2 \mathrm{~s}$ intervals, over a $3 \mathrm{~min}$ period.

Experimental design and statistical analysis. The number of animals used in each experiment is listed in the Results section. The numbers of animals used for biochemical analysis and cognitive testing were based on our previous experience with the techniques, and on the basis of a sample size calculation using preliminary data. For biochemistry, it was estimated that a $40 \%$ change in the mean could be detected in a two group comparison using 3-4 animals/group (assuming a SD of 10\%). Cell/dendrite counts and Western blot data between two groups was analyzed using a two-tailed Student's $t$ test for unpaired variables. For evaluation of doublecortin cell counts across genotypes and injury, twoway ANOVAs were performed using a Holm-Sidak method for multiple-comparisons post hoc test to determine data points with significant differences. For evaluation of context discrimination, twoway repeated-measures ANOVAs were used to determine statistical differences. Either group main effects or interactions of group and trial were used to determine statistical differences. For data that did not pass a Shapiro-Wilk normality test, appropriate nonparametric analysis was performed. Data were considered significant at $p \leq 0.05$ and presented as mean \pm SEM. Statistical analysis was performed using SigmaPlot 11.0 (RRID: SCR_003210).

\section{Results}

Newborn hippocampal neurons die as a result of TBI

The neurons in the hippocampus, a structure critical for learning and memory, have been shown to be vulnerable to various insults (Kirino, 1982; Fischer et al., 1987; Colicos et al., 1996; Baldwin et al., 1997; Conti et al., 1998; Floyd et al., 2002; Gao et al., 2008). In particular, previous studies have shown that doublecortin-positive newborn neurons in the hippocampus die within $24-72 \mathrm{~h}$ after TBI (Gao et al., 2008; Zhao et al., 2016). To confirm this observation, mice were injured (or sham-operated) using the CCI device, and then killed $72 \mathrm{~h}$ after injury. Figure $1 A$ shows representative images of doublecortin immunoreactivity in the dentate gyrus of sham and $72 \mathrm{~h}$ postinjury mice. Consistent with previous reports, an apparent reduction in the number of doublecortin-positive cells can be seen ipsilateral to the injury. Quantification of the number of doublecortin-positive cells revealed significant decreases in both the ipsilateral $(t=4.067, p=0.007)$ and contralateral $(t=3.227, p=0.018)$ hippocampi as a result of TBI (Fig. 1B). 
A
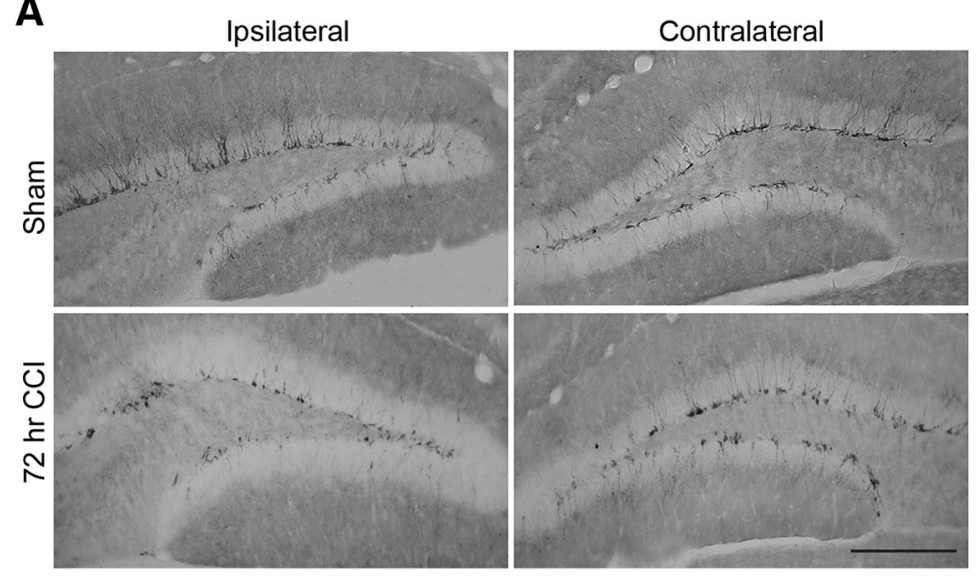

B
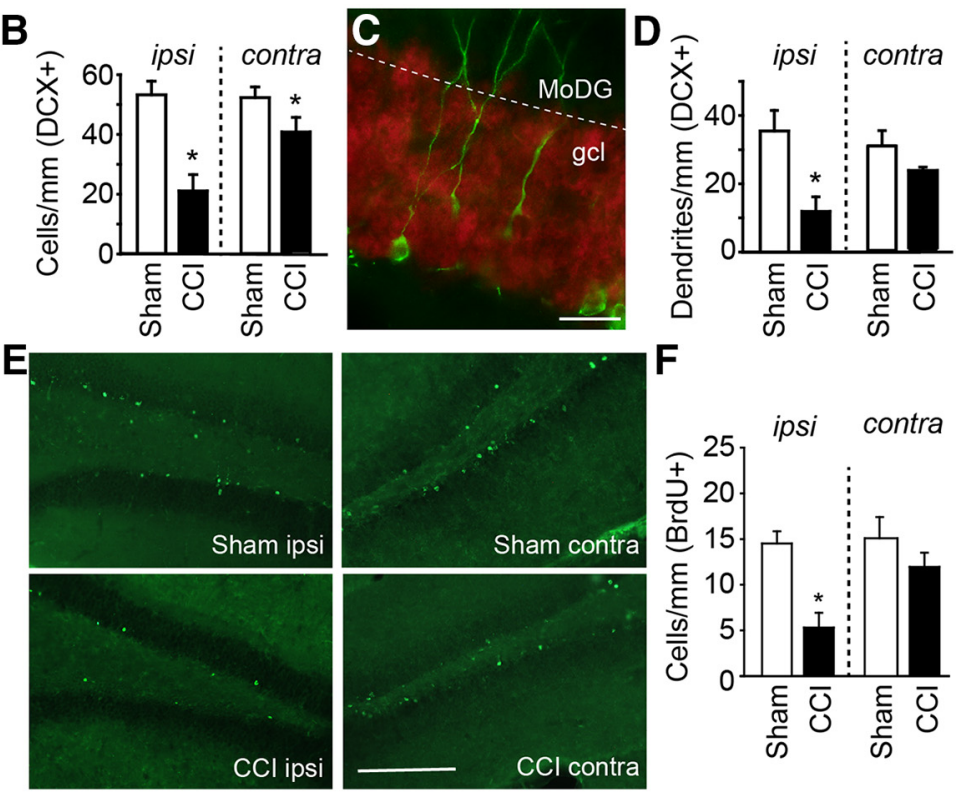

$F$

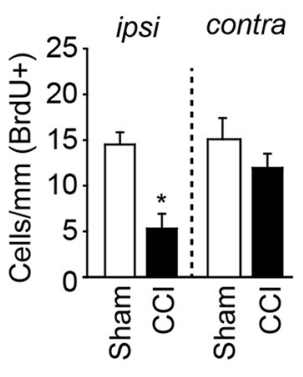

Figure 1. CCl injury results in the loss of hippocampal newborn neurons and shortening of their dendrites. $\boldsymbol{A}$, Representative colorimetric immunohistochemistry of ipsilateral and contralateral hippocampi from sham and $72 \mathrm{~h}$ post-CCl injured mice immunostained with an antibody for doublecortin. Scale bar, $250 \mu \mathrm{m}$. B, Quantification of doublecortin-positive cells ( $n=4 / \mathrm{group}$ ) revealed that $\mathrm{CCl}$ causes a decrease of these cells in both the ipsilateral and contralateral hippocampus compared with sham. C, High-magnification, double-label fluorescent image showing dendritic arborization of newborn neurons stained with doublecortin (green). Mature granule neurons were visualized with an antibody against NeuN (red) gcl, Granule cell layer. Scale bar, 50 $\mu \mathrm{m} . \boldsymbol{D}$, Summary results of doublecortin-positive dendrites ( $n=4 /$ group) extending beyond the granule cell layer (i.e., entering the $\mathrm{MoDG}$ ) revealed that $\mathrm{CCl}$ decreased the number of long doublecortin-positive dendrites. $\boldsymbol{E}$, Representative photomicrographs of BrdU immunoreactivity in the ipsilateral and contralateral hippocampus from sham and $72 \mathrm{~h}$ post-CCl injured mice. Mice had been injected for 3 weeks with BrdU (3 injections per week) before injury (or sham operation). Scale bar, $250 \mu \mathrm{m}$. F, Summary results for the number of BrdU-positive cells in the ipsilateral and contralateral dentate gyrus at $72 \mathrm{~h}$ postinjury compared with sham-operated controls ( $n=4 /$ group). Data are mean \pm SEM. ${ }^{*} p \leq 0.05$. Data are presented as mean \pm SEM.

As newborn neurons mature, their dendrites extend into the molecular layer of the dentate gyrus (MoDG) where they form synaptic connections to integrate into the hippocampal circuit (Fig. 1C). Compared with those seen in the sham controls, the dendrites of the surviving doublecortin-positive cells in the ipsilateral hippocampus were found to be short, and typically did not extend into the molecular cell layer after injury $(t=2.453, p=$ 0.050; Fig. $1 D$ ). A modest reduction in dendrite length was also observed in the contralateral hippocampus, although this did not reach statistical significance $(t=1.223, p=0.261)$.

It is plausible that the reduction in number of doublecortinpositive cells we observed after injury could have resulted from a decrease in doublecortin expression levels or a change in fate determination. To address this possibility, mice were injected with $50 \mathrm{mg} / \mathrm{kg}$ BrdU for 3 weeks ( 3 injections per week, each separated by $48 \mathrm{~h}$ ) to label representative newborn cells. BrdU has a half-life of $\sim 2 \mathrm{~h}$ and only labels cells in the S-phase during this brief "window". Mice were injured (or sham-operated; $n=4$ /group) $5 \mathrm{~d}$ after the final injection. The representative photomicrographs (Fig. 1E) and summary data $(n=4$ /group; Fig. $1 F)$ show that the number of BrdU-positive cells is significantly reduced in the ipsilateral $(t=$ $4.411, p=0.005$ ) hippocampus as a result of injury. Although slightly reduced, no significant difference was seen in the number of contralateral BrdU-positive cells after injury compared with sham controls $(t=1.128, p=0.302)$.

\section{Markers of ER stress can be observed in newborn neurons after injury}

Although it has been observed that dying hippocampal newborn neurons after TBI have fragmented nuclei, a feature of apoptosis (Gao et al., 2008), the signaling pathway(s) that triggers the death of these cells has not been identified. As unresolved ER stress can lead to CHOP-mediated apoptosis (Fig. 2A), we questioned whether markers of ER stress (phosphorylated PERK, phosphorylated eIF $2 \alpha$, CHOP, or activated caspase-3) could be observed in newborn neurons acutely after TBI. Mice were injured (or sham-operated) and killed $6 \mathrm{~h}$ later. The representative photomicrographs shown in Figure $2 B$ indicate that although low levels of phospho-PERK immunoreactivity could be observed in adult granule neurons of the hippocampus in both sham and TBI animals, doublecortin-positive cells were negative of phospho-PERK in sham-operated controls. After TBI, however, a few phosphoPERK-positive newborn neurons could be observed. Similarly, a limited number of newborn neurons ( $2-3 /$ section) were observed expressing phosphoeIF2 $\alpha$, CHOP, or activated caspase- 3 in TBI animals. No double-labeled cells were detected in sham-operated controls.

Loss of CHOP protects newborn neurons after TBI

As our double-label immunohistochemistry indicated that ER stress occurs in hippocampal newborn neurons after injury, we questioned whether CHOP-mediated apoptosis might contribute to the loss of these cells. To address this possibility, we used CHOP knock-out mice. Before initiating these studies, we first verified the genotype of the CHOP mice. As described by the originator of the CHOP KO mice, most of the coding region of $D$ dit3 resides in exons 3-4 of the normal gene, and this region was deleted in CHOP KO mice (Zinszner et al., 1998). The genotyping screen used by Jackson Laboratories uses a 3-primer design (1 common forward, and 2 reverse). One of the reverse 
A

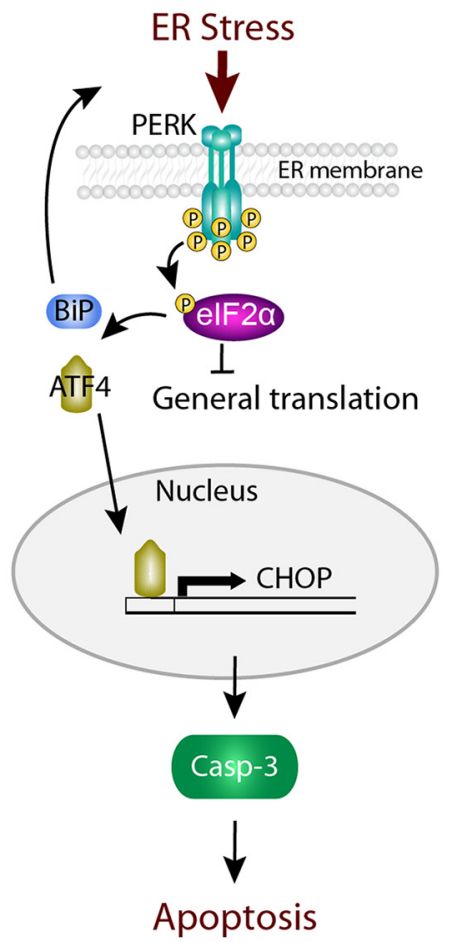

B
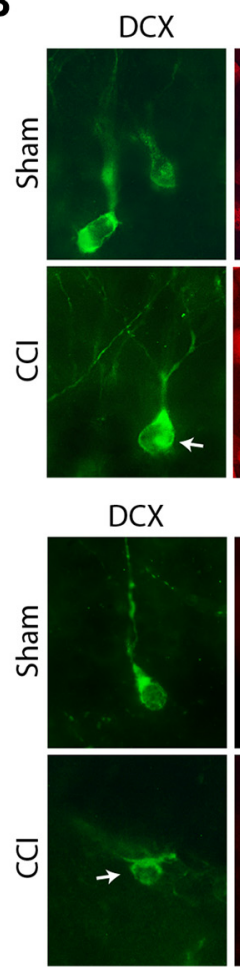

p-PERK

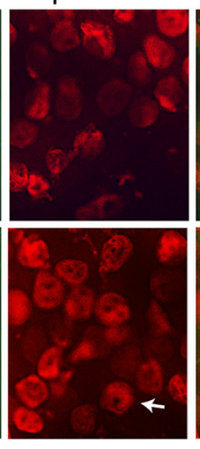

CHOP
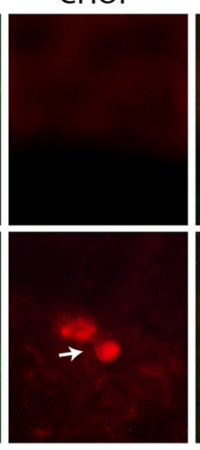

Merge

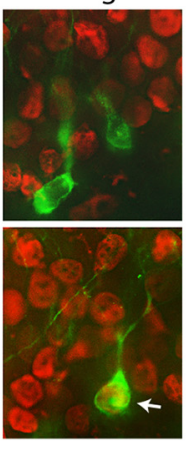

Merge
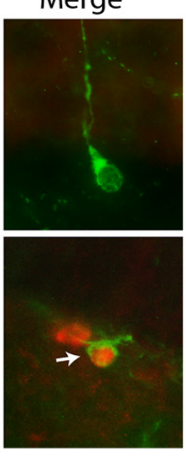

DCX
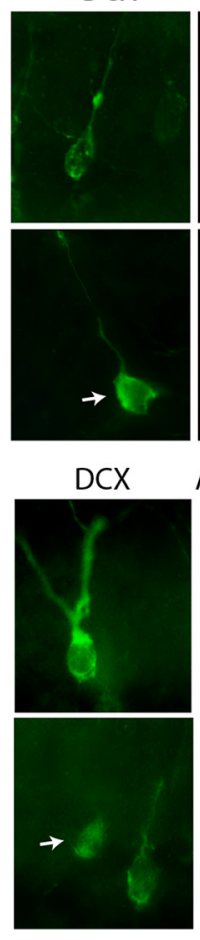

p-elF2a

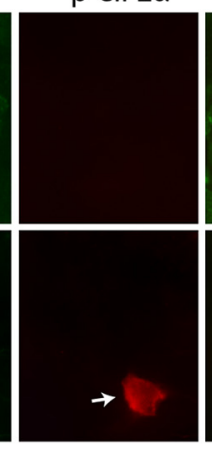

Active casp-3
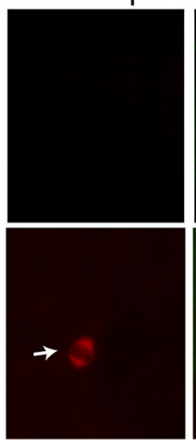

Merge

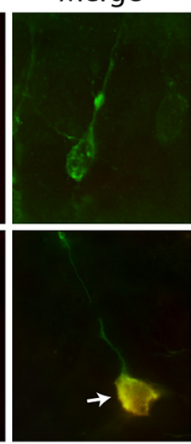

Merge

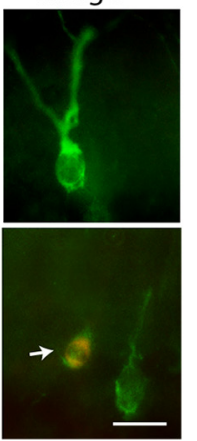

Figure 2. Activation of markers of ER stress in newborn neurons after CCI. A, Drawing showing the PERK-CHOP signaling pathway in response to ER stress. ER stress leads to PERK autophosphorylation which, in turn, results in the phosphorylation of elF $2 \alpha$. Activated elF $2 \alpha$ blocks the translation of 5 '-capped mRNAs. Of exception, messages with internal ribosome entry sites such as the carrier protein BiP (also known as GRP78), ATF4, and CHOP are translated. CHOP increases the expression of genes such as the proapoptotic protease caspase-3 (subsequently activated by proteolytic cleavage), which carry out apoptosis. B, Representative high-magnification photomicrographs of neurons double-immunostained for doublecortin (green), and either phospho-PERK (red), phospho-elF2 (red), CHOP (red), or active caspase-3 (red) in the ipsilateral dentate gyri from sham and $6 \mathrm{~h}$ postinjury mice. Doublecortin-positive cells expressing a marker of ER stress (white arrows) were seen after TBI, but not in sham controls. Scale bar, $25 \mu \mathrm{m}$. Data are presented as mean \pm SEM.

primers amplifies the native gene, whereas the second primer amplifies the mutant gene. Thus, for the WT sequence a $544 \mathrm{bp}$ product is generated, whereas in knock-out mice a 320 bp product is observed. Tissue from CHOP KO and WT mice were used for DNA isolation and PCR amplification. Figure $3 A$ shows a representative image of an ethidium bromide-stained gel showing the amplicons from CHOP KO and WT mice. As expected, DNA from WT mice gave rise to a $544 \mathrm{bp}$ band, whereas amplification from DNA isolated from CHOP KO mice yielded a 320 bp fragment.

To assess whether loss of CHOP improves newborn neuron survival after TBI, groups of WT and CHOP KO mice $(n=$ 4/group) were subjected to CCI injury. Three days after the injury, animals were killed and brain tissue sections prepared for doublecortin immunohistochemistry. Sham-operated WT and CHOP KO mice were used as controls. Representative photomicrographs of doublecortin immunoreactivity within the dorsal ipsilateral hippocampus from sham and CCI CHOP KO mice are shown in Figure 3B. When analyzed using a two-way ANOVA, a significant interaction of genotype and injury condition was detected $(F=11.339, p=0.005)$. Post hoc analysis revealed there was no significant difference in doublecortin-positive cell numbers between sham-operated WT and CHOP KO mice $(t=0.467$, $p=0.647)$, suggesting that, under normal conditions, loss of $\mathrm{CHOP}$ does not affect neurogenesis or newborn neuron survival in the hippocampus. However, after CCI, the number of ipsilateral doublecortin-positive cells in injured $\mathrm{CHOP}$ mice was found to be significantly higher $(t=4.295, p<0.001$; Fig. $3 C)$ than that observed in injured WT mice. A similar protection was observed in the contralateral hippocampus $(F=6.830, p=0.020$ ), with the $\mathrm{CHOP} \mathrm{KO}$ injured mice having significantly more doublecortinpositive cells than WT injured mice $(t=2.913, p=0.011)$.

When the number of doublecortin-positive dendrites that extend into the molecular layer were counted in sham and injured CHOP KO mice (Fig. 3D) and compared with those counted in WT sham and injured mice, a significant interaction of genotype and injury was again observed $(F=11.339, p=0.005)$. The reduction in dendrite numbers seen after injury in the ipsilateral hippocampus of WT mice (WT sham vs WT injured: $t=4.883$, $p<0.001$ ) was not observed in CHOP KO mice (CHOP KO sham vs CHOP KO injured: $t=0.150, p=0.883$ ). No difference between groups was observed in the number of dendrites in the molecular layer of the contralateral hippocampus $(F=0.157, p=$ 0.699).

Previous studies have indicated that $<15 \%$ of 3 -d-old newborn neurons will have dendrites that extend into the molecular layer (Plümpe et al., 2006). Our observation that $\sim 80 \%$ of doublecortin-positive cells in injured CHOP KO mice (measured $3 \mathrm{~d}$ after injury) had long dendrites suggests that these cells were generated before injury, rather than the result of an increase in postinjury proliferation. To specifically address this possibility, tissue sections from sham and $72 \mathrm{~h}$ postinjury WT and CHOP KO mice were immunostained for Ki67, a marker for proliferating cells (Fig. 4A). Ki67-positive cells can be seen implanted along the dentate gyrus, the location where newborn neurons reside. Only cells in contact with the granule cell layer were counted. The summary results ( $n=4$ /group) shown in Figure $4 B$ indicate that loss of CHOP did not significantly alter the number of Ki67- 
A

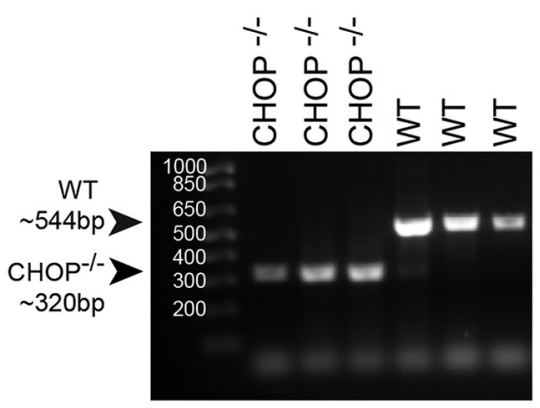

C

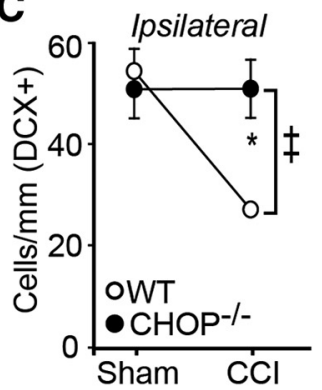

$\frac{1}{1} \div$

Contralateral

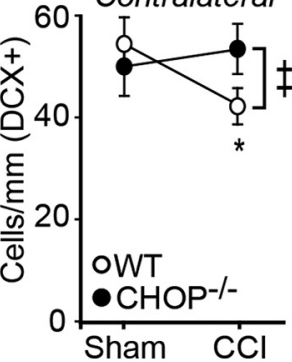

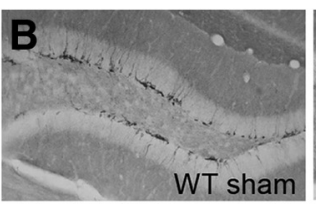
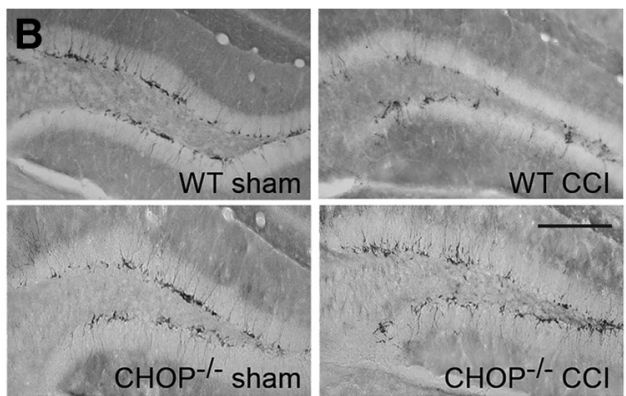

D

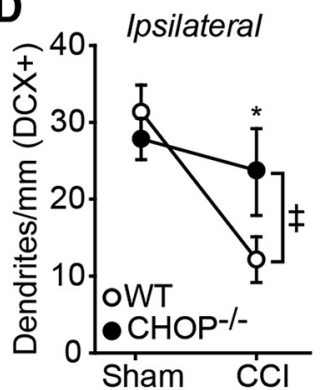

Contralateral

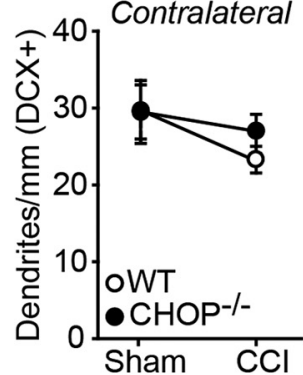

Figure 3. Genetic deletion of $C H O P$ reduces doublecortin cell loss after TBI. $A$, Representative image of an ethidium bromide-stained gel showing the amplicons from $\mathrm{CHOP}^{-/-}$and WT mice.

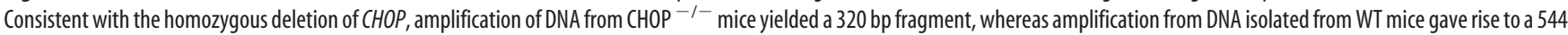
bp band. $\boldsymbol{B}$, Representative photomicrographs of doublecortin immunostained ipsilateral hippocampi from WT sham, $\mathrm{CHOP}^{-1-}$ sham, $72 \mathrm{~h}$ postinjury WT, and $72 \mathrm{~h}$ postinjury $\mathrm{CHOP}{ }^{-1-}$ mice, showing that the visible loss of doublecortin-positive cells in WT injured mice is not seen in injured $\mathrm{CHOP}^{-1-}$ CCl mice. Scale bar, $250 \mu \mathrm{m}$. C, Summary results showing the quantification of doublecortin-positive cells ( $n=4 /$ group) in WT sham, $\mathrm{CHOP}^{-1-}$ sham, $72 \mathrm{~h}$ postinjury WT, and $72 \mathrm{~h}$ postinjury CHOP ${ }^{-1-}$ mice. Compared with WT injured mice, $\mathrm{CHOP}^{-/-}$mice have significantly more immature hippocampal neurons after TBI. $\boldsymbol{D}$, Summary results for the number of doublecortin-positive dendrites ( $n=4 /$ group) entering the molecular layer revealed that by comparison to injured WT mice, injured $\mathrm{CHOP}^{-1-}$ mice had significantly more longer dendrites. $\neq p<0.05$ by two-way ANOVA, ${ }^{*} p<0.05$ between WT and CHOP ${ }^{-/-}$. Data are presented as mean \pm SEM.

A

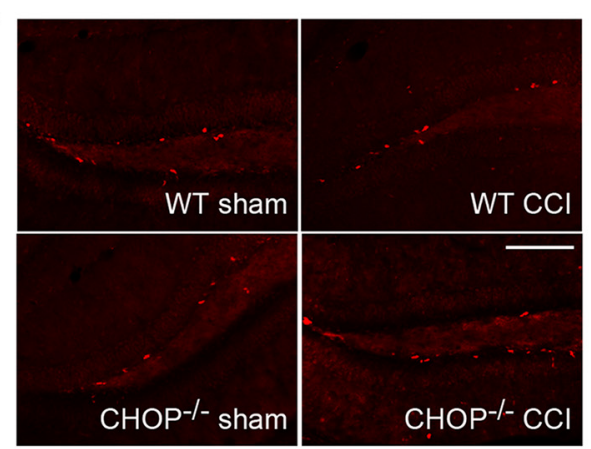

C
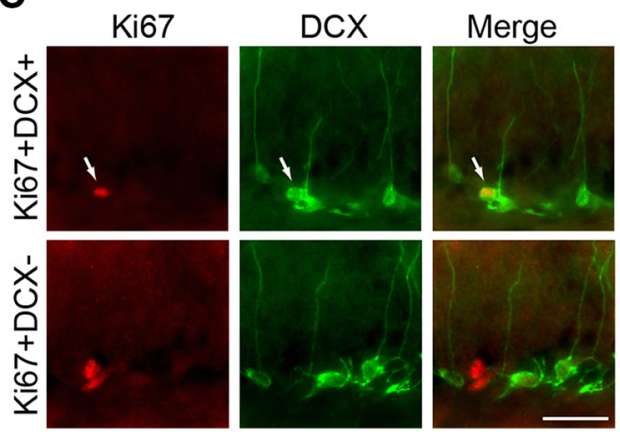

B
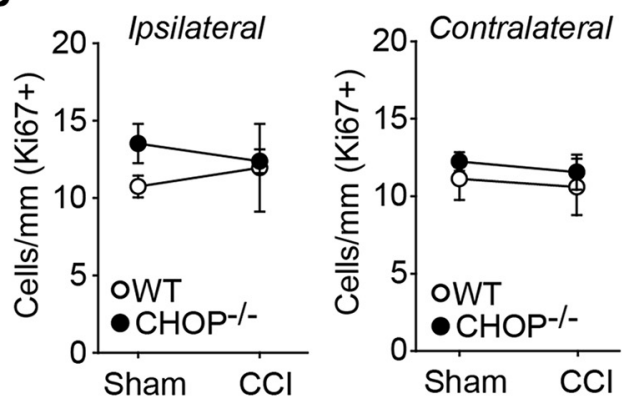

D
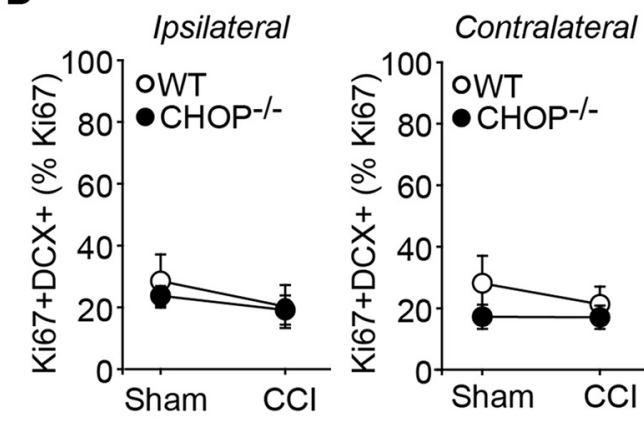

Figure 4. Loss of CHOP does not affect proliferation of neural progenitor cells in the dentate gyrus. $A$, Representative photomicrographs of the ipsilateral dentate gyrus from uninjured and $72 \mathrm{~h}$ postinjury WT and CHOP ${ }^{-1-}$ mice immunostained for the cell proliferation marker Ki67. Ki67-positive cells can be seen implanted along the border of the granule cell layer. Scale bar, $250 \mu \mathrm{m}$. $B$, Summary results for the number of Ki67-positive cells within the granule cell layers show no significant difference between uninjured WT and uninjured $\mathrm{CHOP}^{-1-}$ mice. In addition, no significant difference in Ki67-positive cell numbers was found between $\mathrm{CCI}$-WT and $\mathrm{CCI}-\mathrm{CHOP}^{-1-}$ animals, in either the ipsilateral or contralateral dentate gyrus. C, Representative pictures for Ki67 and doublecortin $(D C X)$ double-label immunohistochemistry. Although a few cells were found to be positive for both Ki67 and doublecortin (Ki67+DCX+; arrow), most Ki67+ cells were found to be $D C X-$. Scale bar, $50 \mu \mathrm{m}$. D, Summary results showing the percentage of Ki67-positive cells that were double-positive for Ki67 and doublecortin in WT sham, $\mathrm{CHOP}^{-1-}$ sham, $72 \mathrm{~h}$ CCI WT, and $72 \mathrm{~h}$ $\mathrm{CCI} \mathrm{CHOP}{ }^{-I-}$ animals. No significant differences were detected in either the ipsilateral or contralateral dentate gyrus across groups. Data are mean \pm SEM. Data are presented as mean \pm SEM. 
A

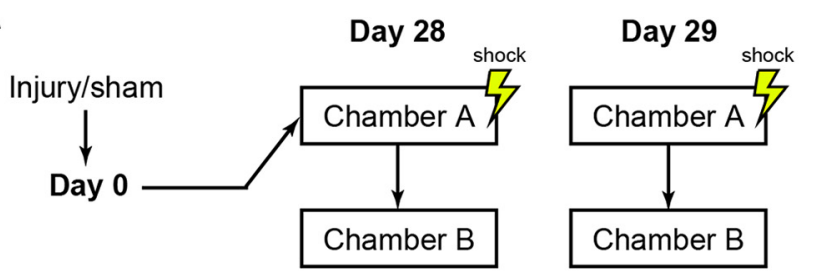

\section{B WT-Sham}

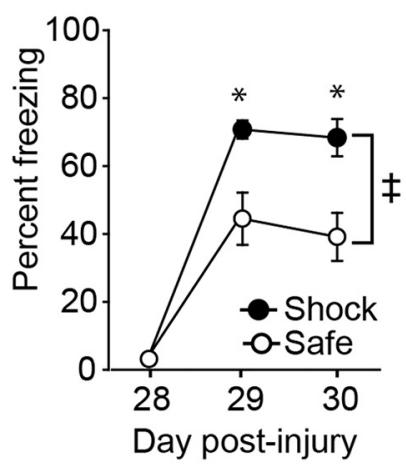

C WT CCl

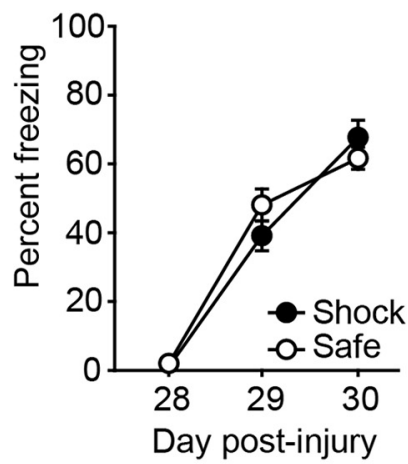

Day 30

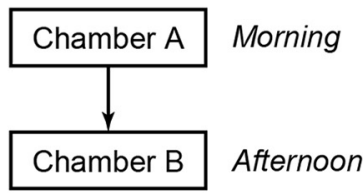

D $\mathrm{CHOP}^{/-} \mathrm{CCl}$

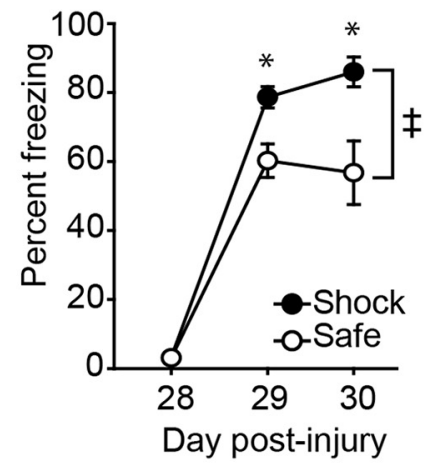

E

E $\quad$ WT
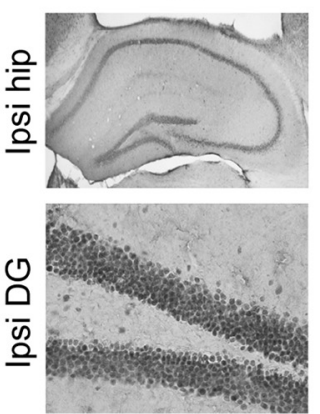

$\mathrm{CHOP}^{-/-}$

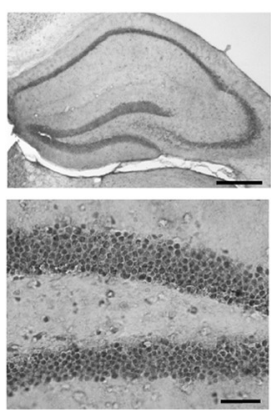

$\mathbf{F}$

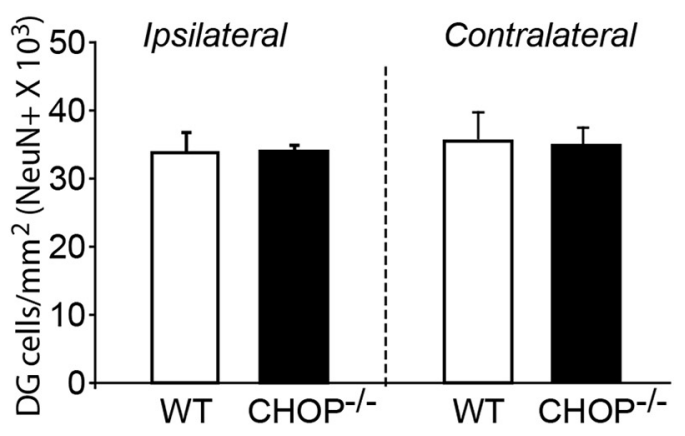

Figure 5. TBI impairs performance in contextual discrimination, which is not observed in injured CHOP knock-out mice. $A$, Schematic showing the timeline of injury and the behavioral testing paradigm in the context fear discrimination task. Testing was performed beginning $28 \mathrm{~d}$ postinjury. Each animal was exposed to Chamber A (shock chamber) and Chamber B (safe chamber) once daily for $3 \mathrm{~d}$. Freezing behavior was monitored and used as an index of fear. Performance (indicated as percentage freezing) in the context discrimination task in $(\boldsymbol{B})$ wild-type shams, $(\boldsymbol{C})$ wild-type injured (WT CCl), and (D) injured $\mathrm{CHOP}^{-1-}$ mice (CHOP $\left.{ }^{-1-} \mathrm{CCl}\right)$. Sham animals show enhanced freezing in the shock versus the safe chamber, indicating intact contextual discrimination. WT CCI mice displayed similar percentage freezing in the shock and safe contexts, indicating impaired contextual discrimination. $\mathrm{CHOP}^{-1-} \mathrm{CCl}$ mice retained the ability to discriminate between the two contexts. Data are mean \pm SEM. $\neq p<0.05$ by two-way ANOVA. *Difference in freezing behavior between shock and safe contexts. $\boldsymbol{E}$, Representative photomicrographs of WT and CHOP ${ }^{-I-}$ hippocampi (Ipsi hip; Scale bar, $500 \mu \mathrm{m}$ ) and dentate gyri (Ipsi DG; Scale bar, $100 \mu \mathrm{m}$ ) immunostained for NeuN. Mice were killed after the completion of the behavioral testing. $\boldsymbol{F}$, Summary results from stereological cell counts of NeuN-positive granule neurons revealed that injured $\mathrm{CHOP}^{-I-}$ mice had no significant difference in the total number of dentate gyrus neurons compared with injured WT animals. Data are presented as mean \pm SEM.

positive cells in either the ipsilateral $(F=0.591, p=0.455)$ or contralateral $(F=0.003, p=0.952)$ dentate gyrus after injury. As Ki67 is not neuron-specific, we performed double-label immunohistochemistry for Ki67 and doublecortin. The representative photomicrographs presented in Figure $4 C$ show that some Ki67+DCX + cells could be found in the granule cell layer, although most were Ki67+DCX - . Quantification of these cells revealed that in sham animals, $\sim 25 \%$ of Ki67-positive cells were double-labeled for doublecortin. This percentage was not altered as a result of injury, nor in CHOP KO mice $(F=0.256, p=0.621)$.

Loss of CHOP improves performance of injured animals in a context discrimination task

As indicated in the Introduction, hippocampal newborn neurons are required for acquisition of context fear discrimination (Saxe et al., 2006). Specifically, studies have demonstrated that stimulation of neurogenesis enhances, while chemical inhibitors of neurogenesis impair, context discrimination (Sahay et al., 2011; Niibori et al., 2012). This influence of neurogenesis on behavior can be observed 4-6 weeks after treatment, a time gap thought to be due to the time required for newborn neurons to begin expressing NR2B-containing NMDA receptors (Denny et al., 2012; Kheirbek et al., 2012b). As we observed that loss of CHOP improves the survival of newborn neurons after injury, we tested whether injured CHOP knock-out mice $(n=9)$ performed better in a context discrimination task (tested starting on day 28 postinjury) compared with injured wild-type $(n=10)$ mice. Training and testing were performed as described in the Materials and Methods section and summarized in Figure $5 A$. A group of shamoperated WT mice was used as a baseline controls $(n=7)$. Figure $5 B$ shows that sham-operated wild-type mice quickly learn to differentiate between the context in which the footshock was delivered (shock) and the similar context in which no footshock occurred (safe), resulting in a significant interaction of freezing behavior over time between the two contexts $(F=16.756, p<$ 0.001 ). By comparison, the results presented in Figure $5 C$ shows that injured wild-type mice were unable to distinguish between 
the "shock and safe" contexts, as indicated by comparable percentage freezing in both contexts $(F=0.033, p=0.859)$. In contrast, injured CHOP KO mice learned to discriminate between the safe and shock contexts $(F=47.88, p<0.001)$, displaying a significant interaction between the context and training day (Fig. 5D). Although injured CHOP KO mice displayed higher overall freezing behaviors, the difference in freezing behavior between the shock and safe (calculated as shock \% freezing - safe \% freezing) contexts was found to be comparable with that seen in uninjured WT controls $(F=0.444, p=0.515)$.

In addition to newborn neurons, mature hippocampal granule neurons also participate in the acquisition of context discrimination (McHugh et al., 2007; Yassa and Stark, 2011). It is therefore possible that the improvement in context fear discrimination we observed in injured CHOP KO mice was due to differences in the number of mature dentate gyrus neurons present at the time of behavioral testing. To address this possibility, mice were killed after the completion of behavioral testing, brain tissue sections prepared, and immunohistochemistry using antibodies to NeuN (a marker of mature neurons) was performed. Figure $5 E$ shows representative images of $\mathrm{NeuN}$-immunostained ipsilateral hippocampi and dentate gyri from injured WT and CHOP KO mice. No areas of overt cell loss were observed in either injured group. Stereological cell counts (Fig. $4 F$ ) of NeuN-positive granule neurons revealed no significant differences between the two groups in the number of mature dentate gyrus neurons in either the ipsilateral $(t=-1.227, p=0.287)$ or contralateral $(t=0.527$, $p=0.617)$ hippocampus.

\section{Inhibition of PERK activity worsens TBI-triggered loss of} newborn neurons and impairs contextual discrimination

PERK is one of the key signaling pathways activated by ER stress. When activated by ER stress, PERK inhibits protein synthesis via phosphorylation of eIF2 $\alpha$, which helps cells to resolve ER stress and return to homeostasis. GSK2606414 has been demonstrated to be a specific inhibitor of PERK, having 100-fold more potency for inhibiting PERK than even closely related eIF $2 \alpha$-kinase (EIF2AK) family members (Axten et al., 2012). Consistent with its ability to inhibit PERK, the phosphorylation of its downstream target eIF $2 \alpha$ is significantly reduced (phospho-eIF $2 \alpha, p=0.004$; phospho-total ratio, $p=0.018$ ) in animals receiving $10 \mu \mathrm{g}$ GSK2606414 (i.c.v.) compared with vehicle-treated controls (Fig. $6 A$ ). The levels of total eIF $2 \alpha$ were not significantly changed as a result of treatment $(p=0.339)$.

To assess whether inhibition of PERK influences newborn neuron loss after TBI, mice ( $n=3$ /group) were injured, then randomly assigned to receive intraperitoneal injections of either $1.7 \mathrm{mg} / \mathrm{kg}$ GSK2606414 or an equal volume of vehicle. Uninjured sham animals treated with either GSK2606414 or vehicle $(n=$ 4 /group) were used as controls. Figure $6 B$ shows that $3 \mathrm{~d}$ after the injury (or sham operation), there was a significant difference in the number of doublecortin-positive cells in the ipsilateral hippocampus as a result of injury $(F=131.558, p<0.001)$, which was exacerbated by GSK2606414 treatment $(t=2.243, p=$ 0.049 ). No effect of the drug was observed on ipsilateral immature neuron numbers in sham mice $(t=0.520, p=0.614)$. In addition, GSK2606414 caused a significant loss $(F=16.593, p=$ 0.002 ) of newborn neurons in the contralateral hippocampus of injured $(t=4.474, p=0.001)$ but not $\operatorname{sham}(t=1.056, p=0.316)$ mice (Fig. 6C).

As inhibition of PERK exacerbated immature neuron loss, we anticipated that this would be associated with a worsening of behavior. As moderate-severely injured mice were incapable of
A
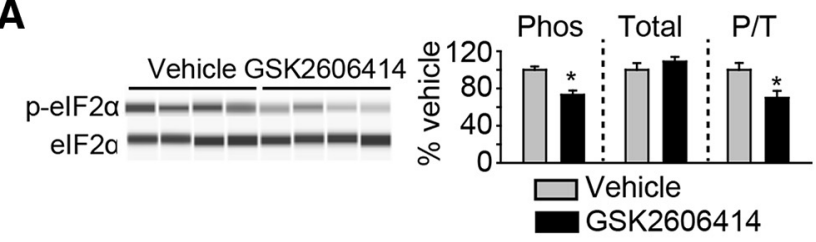

B

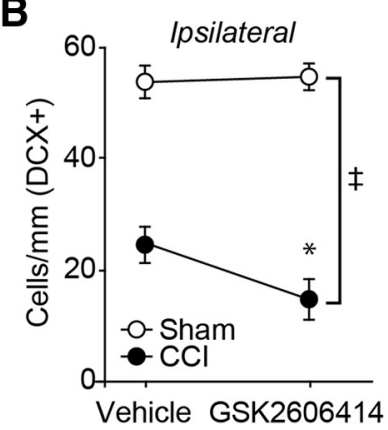

C Contralateral

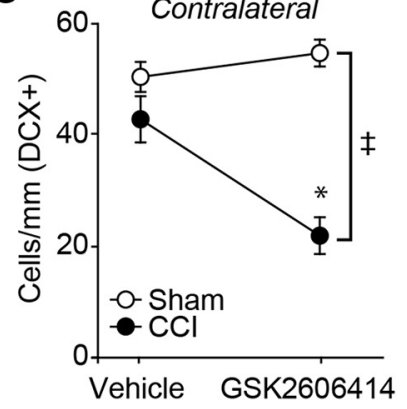

D

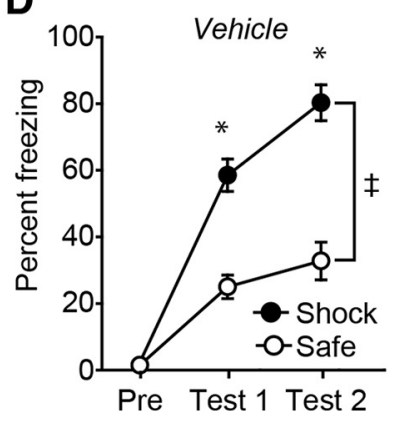

E

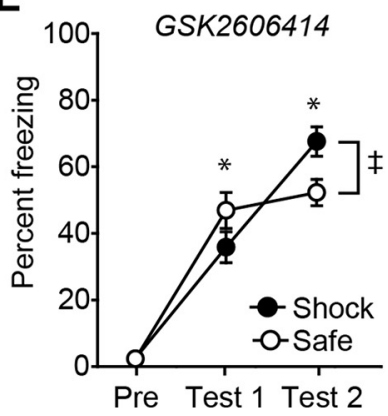

Figure 6. Postinjury administration of the PERKinhibitor GSK2606414 worsens doublecortin cell loss and context fear discrimination. $\boldsymbol{A}$, Representative westerns and summary results showing decreased elf $2 \alpha$ phospho-immunoreactivity (Phos) following intracerebroventricular administration of GSK2606414 (or vehicle) to uninjured mice ( $n=4 /$ group). The total levels of elF $2 \alpha$ did not change as a result of treatment. When calculated as a phospho-total ratio (P/T), a significant decrease in phosphorylation was observed in mice treated with GSK2606414. ${ }^{*} p<$ 0.05 between vehicle and drug-treated animals. $\boldsymbol{B}$, Post-TBI administration of GSK2606414 (1.7 $\mathrm{mg} / \mathrm{kg}$, i.p.) worsens the loss of hippocampal doublecortin-positive cells. Thirty minutes after CCl, mice were injected with GSK2606414 and tissue collected $72 \mathrm{~h}$ postinjury for doublecortin immunohistochemistry. GSK2606414 significantly exacerbated immature neuron loss in the ipsilateral and $(C)$ contralateral hippocampus after TBI compared with $\mathrm{CC}$ animals receiving vehicle. No effect of treatment was observed in sham-operated controls. Data are mean \pm SEM. $\neq p<0.05$ by two-way ANOVA. *Significant difference between vehicle and GSK2606414 treatment. D, Mildly injured, vehicle-treated mice were able to differentiate between the safe and shock contexts (as indicated by significantly increased freezing in the shock context compared with the safe context) when tested beginning $28 \mathrm{~d}$ after injury. $\boldsymbol{E}$, By comparison, mildly injured, GSK2606414-treated (30 min postinjury) mice performed poorly in the context discrimination task compared with vehicle-treated animals. Data are mean \pm SEM. $\neq p<0.05$ by two-way ANOVA. *Difference in freezing behavior between shock and safe contexts. Data are presented as mean \pm SEM.

performing the context discrimination task, a lower magnitude of injury was used to allow us to detect worsening of behavior. When tested in the context fear discrimination task $28 \mathrm{~d}$ postinjury, mildly injured mice treated with vehicle $(n=9)$ were found to be able to distinguish between the two contexts $(F=38.848$, $p<0.001$; Fig. $6 D$ ). In contrast, injured mice treated with 1.7 $\mathrm{mg} / \mathrm{kg}$ GSK2606414 $(n=9)$ showed only minimal enhanced freezing to the shock context by the end of training $(F=11.761$, $p<0.001$; Fig. $6 E)$. When compared with vehicle-treated injured controls, there was a significant difference in the degree of discrimination (calculated as \% freezing in shock - \% freezing in safe for each animal at each time point) between the two groups 
$(F=17.199, p<0.001)$, indicating that injured mice treated with GSK2606414 were impaired in their ability to discriminate between the shock and safe contexts.

Guanabenz reduces TBI-triggered loss of newborn neurons and improves one-trial fear memory

We have previously reported that guanabenz, a drug recently shown to reduce ER stress (Tsaytler et al., 2011), causes dosedependent increases in eIF $2 \alpha$ phosphorylation (Dash et al., 2015). We therefore examined whether guanabenz also offers protection to doublecortin-positive immature neurons. Rats were injured, then administered $5.0 \mathrm{mg} / \mathrm{kg}$ guanabenz (i.p.) or vehicle $30 \mathrm{~min}$ after injury ( $n=6$ /group). Rats were used for these studies as we have observed that guanabenz is not well tolerated by mice (unpublished observation). Groups of sham rats were treated with either vehicle or guanabenz and used as controls ( $n=4 /$ group). Additional drug doses were administered 24 and $48 \mathrm{~h}$ later. The representative images presented in Figure $7 A$ show that CCI causes an apparent loss of doublecortin-positive cells in the ipsilateral hippocampus that is blunted in injured rats treated with guanabenz. Quantification of doublecortin-positive cells revealed a significant difference across groups $(F=39.229$, $p<0.001)$, with postinjury treatment with guanabenz significantly increasing the number of doublecortin-positive neurons in the ipsilateral $(t=2.256, p=$ 0.037 ) hippocampus (Fig. $7 B$ ). No significant difference in doublecortin cell numbers as a result of treatment was seen in sham animals $(t=0.648, p=0.525)$. Contralateral to the injury, the difference in doublecortin-positive immature neuron numbers between sham and CCI animals treated with vehicle $(t=2.699$, $p=0.015)$ was not seen in sham and CCI animals treated with guanabenz $(t=$ $1.138, p=0.270)$. Consistent with the ap-

parent neuroprotection seen ipsilateral to the injury, dendritic arborization was also preserved in animals treated with guanabenz $(F=5.399, p=0.039)$ with the number of doublecortinpositive dendrites exiting the granule cell layer found to be significantly different between TBI animals treated with guanabenz and those treated with vehicle $(t=3.375, p=0.006$; Fig. $7 C)$. There was no effect of guanabenz on dendrite number in uninjured controls $(t=0.089, p=0.931)$, or contralateral to the injury $(F=0.295, p=0.597)$. Although an injury-related increase in the number of Ki67-positive cells was observed in the ipsilateral dentate gyrus $(F=48.250, p<0.001)$, no difference was detected as a result of guanabenz treatment in either the injured ipsilateral $(t=0.183, p=0.858)$ or contralateral $(F=$ $0.0519, p=0.824$ ) hippocampi (Fig. $6 D$ ), suggesting preservation of pre-injury newborn neurons rather than increased postinjury
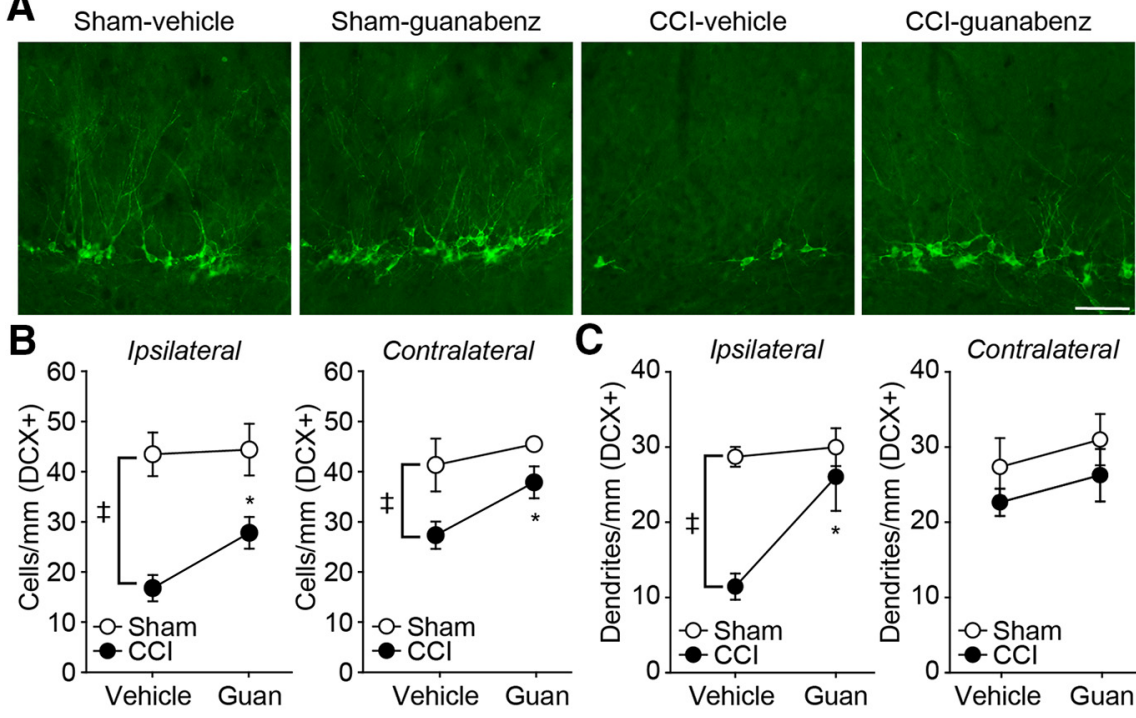

Contralateral
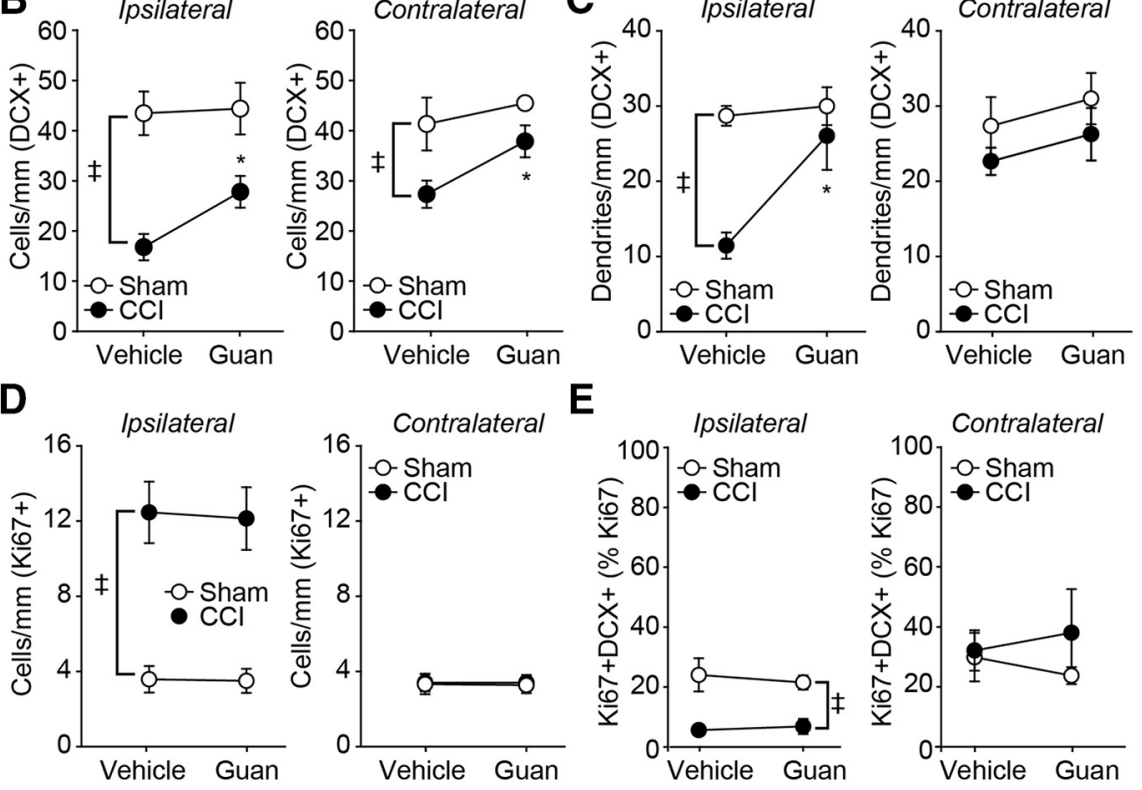

Figure 7. Post-TBI guanabenz administration protects doublecortin-positive cells. $\boldsymbol{A}$, Representative photomicrographs of doublecortin-positive hippocampal newborn neurons in sham (treated with vehicle or $5 \mathrm{mg} / \mathrm{kg}$ guanabenz), and $\mathrm{CCl}$ rats treated with either vehicle or $5 \mathrm{mg} / \mathrm{kg}$ guanabenz. Animals were treated $30 \mathrm{~min}$ after injury (or sham operation) then killed $72 \mathrm{~h}$ later. Scale bar, $100 \mu \mathrm{m}$. B, Summary data ( $n=6 /$ group) of doublecortin-positive cell numbers in sham-vehicle, sham-guanabenz, $\mathrm{CCl}$ and contralateral hippocampi than injured rats treated with vehicle. Guanabenz had no effect on doublecortin-positive

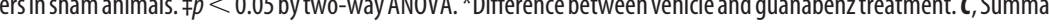
to sham-operated controls. D, Summary data for the number of Ki67-positive cells in vehicle-treated sham, guanabenz-treated cells was observed in the ipsilateral dentate gyrus cell layer as a result of injury, no significant differences were found as a result of double-positive for Ki67 and doublecortin in sham and injured animals treated with either vehicle or guanabenz ( $n=6 /$ group). $\neq p<0.05$ by two-way ANOVA. Data are presented as mean \pm SEM.

neurogenesis. Consistent with this, when Ki67+DCX+ cells were counted, no significant difference was observed as a result of treatment in either $\operatorname{sham}(t=0.538, p=0.601)$ or injured $(t=0.261, p=$ $0.799)$ mice, although a group main effect of injury was observed $(F=24.903, p<0.001)$ due to the presence of a large number of Ki67+DCX - cells.

We next tested whether the protection of newborn neurons was associated with enhanced context fear. We used a one-trial contextual fear task (in the absence of a tone cue), as performance in this task has also been shown to be dependent on hippocampal neurogenesis (Drew et al., 2010). Figure $8 A$ shows that all groups displayed minimal fear to the training chamber before the footshock. When tested $24 \mathrm{~h}$ after training, sham animals $(n=7)$ displayed enhanced freezing behavior indicating that they remembered the training context (Fig. 8B). In contrast, CCI ani- 
A

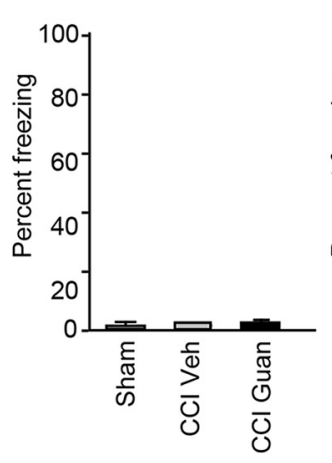

B

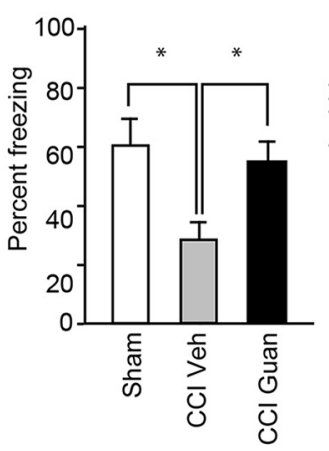

C

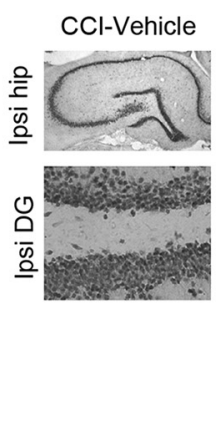

D

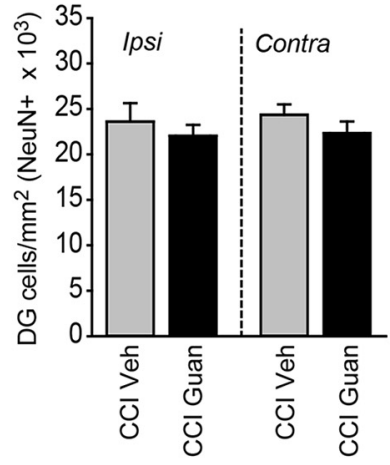

Figure 8. Postinjury administration of guanabenz enhances contextual memory in a one trial contextual fear paradigm. Rats were injured, and then 30 min later received a single injection of either vehicle or $5 \mathrm{mg} / \mathrm{kg}$ guanabenz (i.p.). One-trial contextual fear conditioning was performed on day 28 postinjury. $\boldsymbol{A}$, Before training, all groups showed minimal freezing behavior to the training chamber. $\boldsymbol{B}$, After conditioning, contextual fear memory was tested $24 \mathrm{~h}$ later. Compared with shams $(n=7)$, injured rats treated with vehicle $(n=6)$ displayed significantly decreased freezing when placed back into the training chamber. Guanabenz-treated $\mathrm{CCl}$ animals $(n=6)$ had significantly improved contextual memory as indicated by increased freezing in the training chamber. ${ }^{*} p<0.05$ by one-way ANOVA. C, Animals were killed after the completion of behavioral testing. Representative photomicrographs of NeuN immunostained ipsilateral hippocampi (Ipsi hip; Scale bar, $500 \mu \mathrm{m}$ ) and dentate gyri (Ipsi DG; Scale bar, $100 \mu \mathrm{m}$ ) from vehicle- and guanabenz-treated injured rats. D, Stereological counting of NeuN-positive granule neurons revealed that guanabenz treatment did not significantly alter the total number of dentate gyrus neurons in either the ipsilateral or contralateral hippocampus compared with vehicle-treated injured controls. Data are presented as mean \pm SEM.

mals treated with vehicle $(n=6)$ showed significantly reduced freezing behavior compared with sham controls (post hoc unadjusted $p=0.001$ ), indicating impaired memory. Injured animals treated with guanabenz $(n=6)$ showed improved contextual memory compared with animals treated with vehicle (post hoc unadjusted $p=0.016$ ). After the completion of behavioral testing, animals were killed and hippocampal sections prepared and immunostained using anti-NeuN antibodies. Figure $8 \mathrm{C}$ shows representative images of NeuN-stained ipsilateral hippocampi, and dentate gyri, from vehicle- and guanabenz-treated injured rats. Visual inspection did not reveal any overt loss of mature neurons. When the number of NeuN-positive cells in the dentate gyri were counted using unbiased stereology (Fig. 8D), no differences in neuronal numbers were detected across the treatment groups (ipsilateral: $t=-0.614, p=0.561$; contralateral: $t=$ $0.791, p=0.459)$.

\section{Discussion}

Previous studies have shown that newborn neurons in the adult hippocampus are vulnerable to TBI (Gao et al., 2008; Gibb et al., 2015). However, the signaling pathway(s) that leads to the apoptotic death of these cells following TBI is poorly understood. In the present study, we examined whether ER stress is involved in the death of these cells. The results presented herein revealed three key findings: (1) TBI causes loss of doublecortin cells, in addition to the loss of dendrites in newborn neurons that survive the injury; (2) the PERK inhibitor GSK2606414 exacerbates, whereas the reducer of ER stress guanabenz mitigates, newborn neuron and dendritic loss after TBI; and (3) loss of the proapoptotic transcription factor $\mathrm{CHOP}$ protects against TBI-triggered loss of hippocampal newborn neurons and improves performance in a context fear discrimination task.

Oxidative stress, energy/glucose depletion, and calcium changes are known triggers for ER stress, and all of these have been shown to occur as a result of TBI (Hall and Braughler, 1993; Lee et al., 1999; Harris et al., 2001; van der Vlies et al., 2003; Sullivan et al., 2004; Larner et al., 2006; Clark et al., 2007; Ji et al., 2012; Pandya et al., 2013). Consistent with this, it has been previously demonstrated that TBI increases the levels of ER stress markers (e.g., phosphorylation of eIF2 $\alpha$, IRE, GRP78, ATF4, CHOP) for up to
$21 \mathrm{~d}$ after the injury (Truettner et al., 2007; Begum et al., 2014). We have shown that post-injury administration of an eIF2à phosphatase inhibitor improves cognitive outcome, even when the administration was delayed by $24 \mathrm{hr}$ after injury (Dash et al., 2015). Recently, Chou et al. (2017) found that persistent ER stress contributes to hippocampal dysfunction in two different models of TBI. However, whether ER stress occurs in newborn neurons after TBI had not been examined. Using double-label immunohistochemistry, we found that markers of ER stress could be observed in doublecortin-positive immature neurons after TBI. Specifically, we observed phosphorylated PERK, phosphorylated eIF2 $\alpha$, and CHOP immunostaining in doublecortin-positive cells after injury, immunoreactivities that were not observed in sham-operated controls (Fig. 2).

The proapoptotic transcription factor $\mathrm{CHOP}$ sits at the convergence of three key ER stress signaling cascades: the PERK, IRE-1, and ATF6 pathways. Upon activation, CHOP downregulates survival factors such as $\mathrm{Bcl}-2$ while promoting the transcription of proapoptotic proteins such as BIM (Bcl2-interacting mediator of cell death). In addition, transcriptional profiling experiments have revealed that CHOP increases the expression of GADD34 (thereby reversing the PERK-eIF2 $\alpha$-mediated translational block) and ER oxidoreductase $1 \alpha$ (which promotes oxidizing conditions in the ER; Marciniak et al., 2004). Our immunohistochemical analysis showed that CHOP is expressed in newborn neurons after TBI. Further, we found that TBI-triggered loss of newborn neurons is blunted in CHOP KO mice (Fig. 3).

In addition to loss of doublecortin-positive cells, we and others have previously shown that TBI causes a significant shortening of the dendritic arbors of immature neurons (Zhao et al., 2016). Comparison of the number of doublecortin-positive cells, and the number of dendrites which entered the molecular layer of the dentate gyrus, revealed that $\sim 80 \%$ of all doublecortin-positive cells seen in sham animals had long dendrites. Conversely, only $30 \%$ of the surviving newborn neurons in the ipsilateral hippocampus had dendrites that projected out of the granule cell layer. Interestingly, we observed that $\mathrm{CHOP}$ knock-out animals did not suffer from the TBI-induced reduction of dendritic arbors that was seen in wild-type animals. This suggests that den- 
drites may be susceptible to ER stress, and that dendritic loss as a result of ER stress can occur in the absence of cell death. Previously, we and others have observed that local caspase activation can result in dendritic loss (Mattson et al., 1998a,b; Dash et al., 2000). As caspase activation is a downstream consequence of prolonged ER stress, these findings suggest that ER stress may lead to the "apoptosis" of dendrites in the absence of death of the soma. As neurodegenerative diseases and normal aging cause loss of dendrites, it is interesting to speculate that ER stress may play a causal role in disease- and age-related reductions of neuronal arbors.

Although ATF6 and IRE-1 participate in alleviating ER stress, PERK is thought to play a unique role in deciding cell fate after ER stress (Harding et al., 2000a). Upon activation, PERK phosphorylates eIF $2 \alpha$, which results in the translational inhibition of mRNAs containing a 7-methylguanosine 5'-cap (Fig. 2A). mRNAs that contain an internal ribosome entry site, which include several that code for chaperone proteins that participate in protein folding, and the transcription factor ATF4, which leads to $\mathrm{CHOP}$ induction, are unaffected by this translational block. Although excessive PERK activation can lead to CHOP induction and cell death, several studies have shown that prolonging eIF $2 \alpha$ phosphorylation can reduce ER stress-mediated cell loss (Harding et al., 2000b; Boyce et al., 2005; Liu et al., 2012). Consistent with this, when guanabenz, a recently identified inhibitor of the eIF2 $\alpha$ phosphatase GADD34 (Tsaytler et al., 2011), was administered afterinjury, asignificant preservation of the number ofdoublecortin-positive cells after injury was observed. In contrast, when the PERK inhibitor GSK2606414 was administered, a significant worsening of cell loss was observed. Although these results support a role for PERK in regulating ER stress after TBI, a recent study has reported that guanabenz can reduce ER stress in cells lacking GADD34 (Crespillo-Casado et al., 2017), and that guanabenz acts via inhibition of IRE-1. Regardless of the mechanism by which guanabenz mitigates ER stress, our data show that post-TBI administration of guanabenz reduces newborn neuron loss after TBI and improves a behavior dependent on ongoing neurogenesis.

As the rate of neurogenesis has been previously shown to be increased after TBI (Dash et al., 2001; Kernie and Parent, 2010), it is plausible that some of the newborn neurons seen in response to treatment may have been generated postinjury. Ki67 is a nuclear protein that has been widely used as an early marker of cell proliferation, and indicates cells in the $G_{2}, M$, and latter half of the $S$ phase of the cell cycle (Yu et al., 1992). Previously, it has been shown that the number of proliferating cells is increased in the cortex (predominately astrocytic) and hippocampus (astrocytic and neurogenic) after brain injury (Dash et al., 2001; Kernie et al., 2001). Consistent with these previous studies, we saw a significant increase in the number of Ki67-positive cells in the dentate gyrus ipsilateral to the injury by day 3 after injury in rats. As TBI is known to cause proliferation of immune/inflammatory cells, it is possible that the proliferation of these cells contributed to the increase we observed (Chirumamilla et al., 2002). Consistent with this, only $25 \%$ of Ki67-immunopositive cells were found to be doublecortin-positive, suggesting that the remaining Ki67positive cells are either non-neuronal or have yet to begin expressing doublecortin. In contrast to this finding in injured rats, an increase in KI67-positive cells within the granule neuron layer of the hippocampus was not seen in injured mice. At this time, we are uncertain as to the cause of this differential response in cell proliferation.
One weakness of the present study is that we cannot directly attribute the improved cognitive function to the preservation of doublecortin-positive cells. As other cells also likely experience ER stress, mitigation of ER stress in these cells could have also contributed to the behavioral improvements we observed. Although we did not observe any significant effect of treatment on granule cell numbers, we cannot rule out effects on the function of surviving neurons. For example, Chou and colleagues (2017) have demonstrated that reducing ER stress can improve spatial learning and memory in brain-injured rodents, even when animals are treated 4 weeks after injury, a time point likely beyond the period of ongoing cell death (Chou et al., 2017). The authors also acknowledge that pharmacological agents (such as GSK2606414 and guanabenz) could be having effects beyond their influence on the PERK-CHOP cascade. However, our results from experiments using CHOP knock-out animals strongly implicate ER stress and CHOP activation in the death of immature neurons after TBI. With the above caveats in mind, our findings support a key role for ER stress in the pathophysiology of TBI.

\section{References}

Ambrogini P, Lattanzi D, Ciuffoli S, Agostini D, Bertini L, Stocchi V, Santi S, Cuppini R (2004) Morpho-functional characterization of neuronal cells at different stages of maturation in granule cell layer of adult rat dentate gyrus. Brain Res 1017:21-31. CrossRef Medline

Axten JM, Medina JR, Feng Y, Shu A, Romeril SP, Grant SW, Li WH, Heerding DA, Minthorn E, Mencken T, Atkins C, Liu Q, Rabindran S, Kumar R, Hong X, Goetz A, Stanley T, Taylor JD, Sigethy SD, Tomberlin GH, et al. (2012) Discovery of 7-methyl-5-(1-\{[3-(trifluoromethyl)phenyl]acetyl $\}$ 2,3-dihydro- $1 \mathrm{H}$-indol-5-yl)-7H-p yrrolo [2,3-d] pyrimidin-4-amine (GSK2606414): a potent and selective first-in-class inhibitor of protein kinase R (PKR)-like endoplasmic reticulum kinase (PERK). J Med Chem 55:7193-7207. CrossRef Medline

Baldwin SA, Gibson T, Callihan CT, Sullivan PG, Palmer E, Scheff SW (1997) Neuronal cell loss in the CA3 subfield of the hippocampus following cortical contusion utilizing the optical disector method for cell counting. J Neurotrauma 14:385-398. CrossRef Medline

Begum G, Yan HQ, Li L, Singh A, Dixon CE, Sun D (2014) Docosahexaenoic acid reduces ER stress and abnormal protein accumulation and improves neuronal function following traumatic brain injury. J Neurosci 34:3743-3755. CrossRef Medline

Boyce M, Bryant KF, Jousse C, Long K, Harding HP, Scheuner D, Kaufman RJ, Ma D, Coen DM, Ron D, Yuan J (2005) A selective inhibitor of eIF $2 \alpha$ dephosphorylation protects cells from ER stress. Science 307:935-939. CrossRef Medline

Chirumamilla S, Sun D, Bullock MR, Colello RJ (2002) Traumatic brain injury induced cell proliferation in the adult mammalian central nervous system. J Neurotrauma 19:693-703. CrossRef Medline

Chou A, Krukowski K, Jopson T, Zhu PJ, Costa-Mattioli M, Walter P, Rosi S (2017) Inhibition of the integrated stress response reverses cognitive deficits after traumatic brain injury. Proc Natl Acad Sci U S A 114:E6420E6426. CrossRef Medline

Clark RS, Nathaniel PD, Zhang X, Dixon CE, Alber SM, Watkins SC, Melick JA, Kochanek PM, Graham SH (2007) boc-Aspartyl(OMe)-fluoromethylketone attenuates mitochondrial release of cytochrome $\mathrm{c}$ and delays brain tissue loss after traumatic brain injury in rats. J Cereb Blood Flow Metab 27:316-326. CrossRef Medline

Colicos MA, Dixon CE, Dash PK (1996) Delayed, selective neuronal death following experimental cortical impact injury in rats: possible role in memory deficits. Brain Res 739:111-119. CrossRef Medline

Conti AC, Raghupathi R, Trojanowski JQ, McIntosh TK (1998) Experimental brain injury induces regionally distinct apoptosis during the acute and delayed post-traumatic period. J Neurosci 18:5663-5672. Medline

Crespillo-Casado A, Chambers JE, Fischer PM, Marciniak SJ, Ron D (2017) PPP1R15A-mediated dephosphorylation of eIF $2 \alpha$ is unaffected by Sephin1 or Guanabenz. eLife 6:e26109. CrossRef Medline

Dash PK, Blum S, Moore AN (2000) Caspase activity plays an essential role in long-term memory. Neuroreport 11:2811-2816. CrossRef Medline 
Dash PK, Mach SA, Moore AN (2001) Enhanced neurogenesis in the rodent hippocampus following traumatic brain injury. J Neurosci Res 63:313319. CrossRef Medline

Dash PK, Hylin MJ, Hood KN, Orsi SA, Zhao J, Redell JB, Tsvetkov AS, Moore AN (2015) Inhibition of eukaryotic initiation factor 2 alpha phosphatase reduces tissue damage and improves learning and memory after experimental traumatic brain injury. J Neurotrauma 32:1608-1620. CrossRef Medline

Denny CA, Burghardt NS, Schachter DM, Hen R, Drew MR (2012) 4- to 6-week-old adult-born hippocampal neurons influence novelty-evoked exploration and contextual fear conditioning. Hippocampus 22:11881201. CrossRef Medline

Drew MR, Denny CA, Hen R (2010) Arrest of adult hippocampal neurogenesis in mice impairs single- but not multiple-trial contextual fear conditioning. Behav Neurosci 124:446-454. CrossRef Medline

Fischer TD, Hylin MJ, Zhao J, Moore AN, Waxham MN, Dash PK (2016) Altered mitochondrial dynamics and TBI pathophysiology. Front Syst Neurosci 10:29. CrossRef Medline

Fischer W, Wictorin K, Björklund A, Williams LR, Varon S, Gage FH (1987) Amelioration of cholinergic neuron atrophy and spatial memory impairment in aged rats by nerve growth factor. Nature 329:65-68. CrossRef Medline

Floyd CL, Golden KM, Black RT, Hamm RJ, Lyeth BG (2002) Craniectomy position affects morris water maze performance and hippocampal cell loss after parasagittal fluid percussion. J Neurotrauma 19:303-316. CrossRef Medline

Gao X, Chen J (2009) Conditional knockout of brain-derived neurotrophic factor in the hippocampus increases death of adult-born immature neurons following traumatic brain injury. J Neurotrauma 26:1325-1335. CrossRef Medline

Gao X, Deng-Bryant Y, Cho W, Carrico KM, Hall ED, Chen J (2008) Selective death of newborn neurons in hippocampal dentate gyrus following moderate experimental traumatic brain injury. J Neurosci Res 86:22582270. CrossRef Medline

Gibb SL, Zhao Y, Potter D, Hylin MJ, Bruhn R, Baimukanova G, Zhao J, Xue H, Abdel-Mohsen M, Pillai SK, Moore AN, Johnson EM, Cox CS Jr, Dash PK, Pati S (2015) TIMP3 attenuates the loss of neural stem cells, mature neurons and neurocognitive dysfunction in traumatic brain injury. Stem Cells 33:3530-3544. CrossRef Medline

Hall ED, Braughler JM (1993) Free radicals in CNS injury. Res Publ Assoc Res Nerv Ment Dis 71:81-105. Medline

Harding HP, Novoa I, Zhang Y, Zeng H, Wek R, Schapira M, Ron D (2000a) Regulated translation initiation controls stress-induced gene expression in mammalian cells. Mol Cell 6:1099-1108. CrossRef Medline

Harding HP, Zhang Y, Bertolotti A, Zeng H, Ron D (2000b) Perk is essential for translational regulation and cell survival during the unfolded protein response. Mol Cell 5:897-904. CrossRef Medline

Harris LK, Black RT, Golden KM, Reeves TM, Povlishock JT, Phillips LL (2001) Traumatic brain injury-induced changes in gene expression and functional activity of mitochondrial cytochrome $\mathrm{C}$ oxidase. J Neurotrauma 18:993-1009. CrossRef Medline

He CH, Gong P, Hu B, Stewart D, Choi ME, Choi AM, Alam J (2001) Identification of activating transcription factor 4 (ATF4) as an Nrf2-interacting protein: implication for heme oxygenase-1 gene regulation. J Biol Chem 276: 20858-20865. CrossRef Medline

Hotamisligil GS, Davis RJ (2016) Cell signaling and stress responses. Cold Spring Harb Perspect Biol 8:a006072. CrossRef Medline

Jessberger S, Clark RE, Broadbent NJ, Clemenson GD Jr, Consiglio A, Lie DC, Squire LR, Gage FH (2009) Dentate gyrus-specific knockdown of adult neurogenesis impairs spatial and object recognition memory in adult rats. Learn Mem 16:147-154. CrossRef Medline

Ji J, Kline AE, Amoscato A, Samhan-Arias AK, Sparvero LJ, Tyurin VA, Tyurina YY, Fink B, Manole MD, Puccio AM, Okonkwo DO, Cheng JP, Alexander H, Clark RS, Kochanek PM, Wipf P, Kagan VE, Bayır H (2012) Lipidomics identifies cardiolipin oxidation as a mitochondrial target for redox therapy of brain injury. Nat Neurosci 15:1407-1413. CrossRef Medline

Kernie SG, Parent JM (2010) Forebrain neurogenesis after focal ischemic and traumatic brain injury. Neurobiol Dis 37:267-274. CrossRef Medline

Kernie SG, Erwin TM, Parada LF (2001) Brain remodeling due to neuronal and astrocytic proliferation after controlled cortical injury in mice. J Neurosci Res 66:317-326. CrossRef Medline
Kheirbek MA, Klemenhagen KC, Sahay A, Hen R (2012a) Neurogenesis and generalization: a new approach to stratify and treat anxiety disorders. Nat Neurosci 15:1613-1620. CrossRef Medline

Kheirbek MA, Tannenholz L, Hen R (2012b) NR2B-dependent plasticity of adult-born granule cells is necessary for context discrimination. J Neurosci 32:8696-8702. CrossRef Medline

Kirino T (1982) Delayed neuronal death in the gerbil hippocampus following ischemia. Brain Res 239:57-69. CrossRef Medline

Larner SF, Hayes RL, Wang KK (2006) Unfolded protein response after neurotrauma. J Neurotrauma 23:807-829. CrossRef Medline

Lee SM, Wong MD, Samii A, Hovda DA (1999) Evidence for energy failure following irreversible traumatic brain injury. Ann N Y Acad Sci 893:337340. CrossRef Medline

Liu CL, Li X, Hu GL, Li RJ, He YY, Zhong W, Li S, He KL, Wang LL (2012) Salubrinal protects against tunicamycin and hypoxia induced cardiomyocyte apoptosis via the PERK-eIF2alpha signaling pathway. J Geriatr Cardiol 9:258-268. CrossRef Medline

Marciniak SJ, Yun CY, Oyadomari S, Novoa I, Zhang Y, Jungreis R, Nagata K, Harding HP, Ron D (2004) CHOP induces death by promoting protein synthesis and oxidation in the stressed endoplasmic reticulum. Genes Dev 18:3066-3077. CrossRef Medline

Mattson MP, Keller JN, Begley JG (1998a) Evidence for synaptic apoptosis. Exp Neurol 153:35-48. CrossRef Medline

Mattson MP, Partin J, Begley JG (1998b) Amyloid $\beta$-peptide induces apoptosis-related events in synapses and dendrites. Brain Res 807:167176. CrossRef Medline

McClelland JL, Goddard NH (1996) Considerations arising from a complementary learning systems perspective on hippocampus and neocortex. Hippocampus 6:654-665. CrossRef Medline

McHugh TJ, Jones MW, Quinn JJ, Balthasar N, Coppari R, Elmquist JK, Lowell BB, Fanselow MS, Wilson MA, Tonegawa S (2007) Dentate gyrus NMDA receptors mediate rapid pattern separation in the hippocampal network. Science 317:94-99. CrossRef Medline

Niibori Y, Yu TS, Epp JR, Akers KG, Josselyn SA, Frankland PW (2012) Suppression of adult neurogenesis impairs population coding of similar contexts in hippocampal CA3 region. Nat Commun 3:1253. CrossRef Medline

Opendak M, Gould E (2015) Adult neurogenesis: a substrate for experiencedependent change. Trends Cogn Sci 19:151-161. CrossRef Medline

Osier N, Dixon CE (2016) The controlled cortical impact model of experimental brain trauma: overview, research applications, and protocol. Methods Mol Biol 1462:177-192. CrossRef Medline

Pandya JD, Nukala VN, Sullivan PG (2013) Concentration dependent effect of calcium on brain mitochondrial bioenergetics and oxidative stress parameters. Front Neuroenergetics 5:10. CrossRef Medline

Plümpe T, Ehninger D, Steiner B, Klempin F, Jessberger S, Brandt M, Römer B, Rodriguez GR, Kronenberg G, Kempermann G (2006) Variability of doublecortin-associated dendrite maturation in adult hippocampal neurogenesis is independent of the regulation of precursor cell proliferation. BMC Neurosci 7:77. CrossRef Medline

Sahay A, Scobie KN, Hill AS, O'Carroll CM, Kheirbek MA, Burghardt NS, Fenton AA, Dranovsky A, Hen R (2011) Increasing adult hippocampal neurogenesis is sufficient to improve pattern separation. Nature 472:466470. CrossRef Medline

Saxe MD, Battaglia F, Wang JW, Malleret G, David DJ, Monckton JE, Garcia AD, Sofroniew MV, Kandel ER, Santarelli L, Hen R, Drew MR (2006) Ablation of hippocampal neurogenesis impairs contextual fear conditioning and synaptic plasticity in the dentate gyrus. Proc Natl Acad Sci U S A 103:17501-17506. CrossRef Medline

Spalding KL, Bergmann O, Alkass K, Bernard S, Salehpour M, Huttner HB, Boström E, Westerlund I, Vial C, Buchholz BA, Possnert G, Mash DC, Druid H, Frisén J (2013) Dynamics of hippocampal neurogenesis in adult humans. Cell 153:1219-1227. CrossRef Medline

Sullivan PG, Springer JE, Hall ED, Scheff SW (2004) Mitochondrial uncoupling as a therapeutic target following neuronal injury. J Bioenerg Biomembr 36:353-356. CrossRef Medline

Sun D, McGinn M, Hankins JE, Mays KM, Rolfe A, Colello RJ (2013) Agingand injury-related differential apoptotic response in the dentate gyrus of the hippocampus in rats following brain trauma. Front Aging Neurosci 5:95. CrossRef Medline 
Treves A, Rolls ET (1992) Computational constraints suggest the need for two distinct input systems to the hippocampal CA3 network. Hippocampus 2:189-199. CrossRef Medline

Truettner JS, Hu B, Alonso OF, Bramlett HM, Kokame K, Dietrich WD (2007) Subcellular stress response after traumatic brain injury. J Neurotrauma 24:599-612. CrossRef Medline

Tsaytler P, Harding HP, Ron D, Bertolotti A (2011) Selective inhibition of a regulatory subunit of protein phosphatase 1 restores proteostasis. Science 332:91-94. CrossRef Medline

van der Vlies D, Makkinje M, Jansens A, Braakman I, Verkleij AJ, Wirtz KW, Post JA (2003) Oxidation of ER resident proteins upon oxidative stress: effects of altering cellular redox/antioxidant status and implications for protein maturation. Antioxid Redox Signal 5:381387. CrossRef Medline

van Praag H, Schinder AF, Christie BR, Toni N, Palmer TD, Gage FH (2002) Functional neurogenesis in the adult hippocampus. Nature 415:10301034. CrossRef Medline

Walter P, Ron D (2011) The unfolded protein response: from stress pathway to homeostatic regulation. Science 334:1081-1086. CrossRef Medline

Wek RC, Cavener DR (2007) Translational control and the unfolded protein response. Antioxid Redox Signal 9:2357-2371. CrossRef Medline

Yassa MA, Stark CE (2011) Pattern separation in the hippocampus. Trends Neurosci 34:515-525. CrossRef Medline

Yu CC, Woods AL, Levison DA (1992) The assessment of cellular proliferation by immunohistochemistry: a review of currently available methods and their applications. Histochem J 24:121-131. CrossRef Medline

Zhao Y, Gibb SL, Zhao J, Moore AN, Hylin MJ, Menge T, Xue H, Baimukanova G, Potter D, Johnson EM, Holcomb JB, Cox CS Jr, Dash PK, Pati S (2016) Wnt3a, a protein secreted by mesenchymal stem cells is neuroprotective and promotes neurocognitive recovery following traumatic brain injury. Stem Cells 34:1263-1272. CrossRef Medline

Zinszner H, Kuroda M, Wang X, Batchvarova N, Lightfoot RT, Remotti H, Stevens JL, Ron D (1998) CHOP is implicated in programmed cell death in response to impaired function of the endoplasmic reticulum. Genes Dev 12:982-995. CrossRef Medline 